\title{
THE ROMAN FRONTIER IN DOBRUDJA. SEVERAL FORTIFICATIONS NOT EXCAVATED OR WITH UNDETERMINED PLANIMETRIC FEATURES
}

\begin{abstract}
Eight different fortifications of unequal size and strategic importance are tackled in this contribution, namely the ones along the Danube limes, starting at Seimenii Mari, Stânca Topalu - Cariera Cekirgea, Gârliciu - Cius, Luncavița - Milan, Isaccea - Noviodunum, Tulcea-Aegyssus, and two more Late Roman quadriburgia, controlling the inner roads at Mihai Bravu and Mircea Vodă. Excepting for Noviodunum and Aegyssus, none of the above mentioned limes forts was subject to thorough archaeological investigations which is why all of them entered lately into the scope of the Romanian LIMES National Programme. As a matter of fact, within the framework of the World Heritage List nomination preparings, the entire Lower Danube Roman frontier became subject to detailed surveys and drone flight records (with orthographic and oblique shots) which were corroborated with all the information available so far in the archives. Therefore, a partial Forschungsstand for all this intensive research is presented in the following pages. Our approach is formally a holistic one, aiming at integrating and understanding the dynamics of both limes and interior communities, covering their communication mediums, landscape and resources. In this respect, new promising steps were also taken for identifying civitas Ausdecensium at Cetatea (commune of Dobromir, Constanța county), in southern Dobrudja. What we already know for sure is that in the 4th century the members of a prosperous habitation along the imperial road from Marcianopolis, running through Zaldapa, Tropaeum Traiani (possibly, Mircea Vodă) and Ulmetum, to Noviodunum peacefully dwelt within the area of the modern village.
\end{abstract}

Keywords: Roman Period, Roman Army, Lower Danube, Roman frontiers, fortifications, Moesia inferior/Scythia.

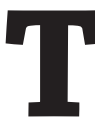

his paper represents an updated synthesis of the most recent results yielded by multidisciplinary research carried out in a number of Roman fortifications by the Lower Danube frontier, within the LIMES National Programme ${ }^{1}$. The results of field data collection through field walks, surveys and drone flight records (orthographic and oblique photos and shots $)^{2}$, corroborated with the current available archives information,

\footnotetext{
${ }^{1}$ http://limesromania.ro

2 Daniel Costea - https://filmarecudrona.ro/
}

\section{Ioan C. OPRIȘ}

University of Bucharest

ioan_opris@yahoo.com

\section{Ovidiu ȚENTEA}

National Museum of Romanian History ovidiu.tentea@gmail.com

\section{Vlad CĂLINA}

National Museum of Romanian History calina.nicolae@gmail.com

DOI: $10.14795 /$ j.v7i4.582

ISSN $2360-266 \mathrm{X}$

ISSN-L 2360 - 266X 
provided us with the opportunity to reshape some layouts, entirely or only partially, known to date, of certain fortifications (Stânca Topalu - Cariera Cekirgea, Gârliciu - Cius, Luncavița - Milan, Isaccea - Noviodunum, Tulcea Aegyssus, Mircea Vodă), and also take a few material steps for a more accurate location of some of the sites, like for instance, the burgus/praesidium of Seimenii Mari. An extended report has been recently published ${ }^{3}$, from which we chose and detailed most significant novelties (Fig. 1).

\section{SEIMENII MARI}

The Roman fortification (Fig. 2-5) laid north of Cernavodă city, between the Seimenii Mari and Seimenii Mici villages, on a plateau nearby the Danube. Respective plateau was known, by early last century, to the natives as the "La Cetate". The fortress was situated at ca. $1 \mathrm{~km}$ south the limit of the Seimenii Mari village, on the steep bank of the Danube. The ancient name of the Seimenii Mari fortification is not yet mentioned either in the Itinerarium Antonini Augusti (224) or Tabula Peutingeriana (VIII, 3).

Upon the analysis of Pamfil Polonic's notes and drawing, we arrived at a few conclusions based on comparisons with recent date aerial photos. The fortification itself was destroyed by the end of the 19th century. The ca. 60 ha plateau surface was surrounded, according to Pamfil Polonic, by an approximately $2 \mathrm{~km}$ long Roman rampart. Towards the east, a $15 \mathrm{~m}$ wide and 1-2 $\mathrm{m}$ deep defensive ditch was still visible by the end of the 19 th century. In the drawing drafted at that time, the rampart is figured by its northern and eastern stretches. The same author argued that the Roman fortification lying towards the Danube would have been in a rectangular shape with at least $80 \mathrm{~m}$ sides. At a later date, a tower with a $20 \mathrm{~m}$ eastern side was built. In the area, namely the multi-layered settlement that lay south the modern village were reported and published Hellenistic amphorae (Thasos, Heraclea Pontica, Sinope and pseudo-Cos). The issue that remains still unresolved, for the lack of a conclusive archaeological diagnostic, concerns the dating of the vallum-enclosed settlement (ancient, as Pamfil Polonic believed, or of late date, possibly even a protoBulgarian fortification, according to S. Torbatov ${ }^{5}$ ).

Other issues worth mentioning would be the finding of two milestones dated to $\mathrm{AD} 160^{6}$, respectively $\mathrm{AD}$ $200^{7}$ and a dedicatory inscription (Bauinschrift) ${ }^{8}$, dated between AD 293-305 that must have been set up above the Tetrarchic fortification gate (burgus/ praesidium) ${ }^{9}$, whose $2 \mathrm{~m}$-thick walls were still visible to Pamfil Polonic. Respective epigraphic pieces have proven to be key in the accurate mapping of the fortified site of Seimenii Mari. It

\footnotetext{
TENTEA et alii 2019.

${ }^{4}$ TOCILESCU 1887, 29, no. 21; FLORESCU 1924; IRIMIA 1980, 103, 115 ; POLONIC 1935, 21; ZAHARIADE/GUDEA 1997, 78 -79; SUCEVEANU/ BARNEA 1991, 181; GUDEA 2005, 447-448, no. 39; BĂJENARU 2010, 128. See also the most recent and significant paper on the site, OPRIȘ 2019.

TORBATOV 2002, 101-102.

6 ISM V, 1.

ISM V, 2.

8 TOCILESCU 1887, 29, no. 21 = CIL III, $7487=$ ISM IV, $246=$ IGLR 205.

9 IGLR, 213
}

lay on the Danube bank, along the strategic limes road (via militaris), at a six miles distance (sex milia passuum) from Axiopolis, according to the two milestones discovered in the south-western part of the civil settlement.

With respect to the marble Tetrarchic founding inscription, it lists the local fortification of Seimenii Mari among a series of important fortifications by the Lower Danube, built or rebuilt a fundamentis: Zernes/ Donje Butorke, Sexaginta Prista/ Ruse, Transmarisca/ Tutrakan, Durostorum/ Silistra and Halmyris/ Murighiol during Diocletian's rule.

The mapping of the numismatic data for the Seimenii Mari, Seimenii Mici and the neighbouring areas aimed at a better understating of the anthropic use of the territory and concurrently, a dating attempt of the identified settlements, sketched between Aurelian's reign and the 5th century Hunnic raids with a revival under Justinian or Tiberius II Constantine (coins minted in AD 538/539 or 580/581). This approach also incorporated several field walks and older or more recent field assessments on the Siliștea valley (with lakes Domneasca Mare and Domneasca Mică) or along the lake succession Purcăreți, Ramazan (Ramadan) and T,ibrinu. In respective occasions were identified Hallstatt date settlement traces (Babadag I-II), Latène, of the Principate and late Roman date, Romano-Byzantine and then, again, Mid-Byzantine ("Dridu" elements), utilizing the advantageous habitation areas next to the Danube and the deep tributary valleys (river havens taking the form of a fluvial liman or of blocked valley lakes).

\section{STÂNCA TOPALU (CEKIRGEA QUARRY) ${ }^{10}$}

The fortification is located on Stânca Topalu, on a headland located at $4 \mathrm{~km}$ north the Topalu village (Fig. 6 - 8). Access is made from county road DJ 223, then on a 2 $\mathrm{km}$ farm land. The limestone massive on top of which lay the fortification is part of the Topalu Neo-Jurassic Reef, a geologic reserve of national importance.

The fortification was built on a $40 \mathrm{~m}$ high limestone massif, which in Antiquity provided enhanced visibility towards Carsium, by the end of Scârția valley (or Cekirgea/ Cichirgeana), where a stone quarry operated - also known as the Margella quarry. The Roman fortification was rectangular with ca. 170 x $116 \mathrm{~m}$ sides, the ancient ruins being still visible on the surface in 1890 . Most part of the western and northern sides was destroyed by an older stone quarry, today the monument's surface measuring approximately only 0.66 ha. Pamfil Polonic appreciated that the general area of the fortification, when he could document it in the last decade of the 19th century, was somewhere around 1.75 ha, possibly even towards 2 ha. According to his measurements, the fortification was surrounded by a $10 \mathrm{~m}$ wide and $1 \mathrm{~m}$ high vallum (of which today a $20 \mathrm{~m}$ wide and 2-3 m deep stretch may be still distinguished, respectively the ditch). Two gates would have set up on the eastern side. The southern side measured $116 \mathrm{~m}$, that in the east was $140 \mathrm{~m}$, the northern was $104 \mathrm{~m}$, while that in the west, the largest, no

\footnotetext{
10 PÂRVAN 1914, col. 430-431; POLONIC 1935, 21-22; ZAHARIADE/ GUDEA 1997, 79; GUDEA 2005, 448-449, No. 41. See also the comprehensive approach in OPRIȘ/DOBRINESCU 2018, 181-204.
} 
less than $170 \mathrm{~m}$. P. Polonic mentions at the time of his visit that walls belonging to internal buildings were still visible, together with the information of the many vessels and coins discovered over the course of time by quarry workers.

Grigore Florescu conducted a brief research at Topalu (in 1924 or 1927?), concluding that the building system of the external wall face was very much alike that already found in the fortifications at Seimeni and Capidava. In 2006, a sondage was performed within the fortification in order to acquire stratigraphic information. It was accomplished after previous field walks, when Romano-Byzantine and Hallstatt pottery fragments (of Babadag II type) had already been collected from the collapsed archaeological layers from steep northern and western banks of the hilltop. Upon the analysis of the collected pottery material during the intrusive 2006 assessment - LRC/ Phocean Red Slip Ware Hayes 3 type bowl fragments; a "carrot-shaped" amphora; cooking pots with finger impressions and notches on the lip; bronze coin of Constantius II (337-361) - it may be hypothesized that the fortification functioned sometime during the 5 th - early 6 th century AD.

Recent approaches incorporated said archaeological records, the digital data collected via drone-aid as well onsite observations. These highlighted the unaltered side of the fortification enclosure, even an internal detail, respectively a ca. $18 \mathrm{~m}$ long building, provided with an apsis (basilica?).

\section{GÂRLICIU (CIUS) ${ }^{11}$}

The fortification was built on a headland (Fig. 9-11) located by the end of a narrow peninsula advancing parallel to the Danube, today delimiting the Hisarlâk lake from northeast. The river course lies today at a distance of more than 4.5 $\mathrm{km}$ north-westwards. The site is located at $4.5 \mathrm{~km}$ south the Gârliciu commune, with access from county road DJ 222F, intersecting the national road DN $22 \mathrm{~A}$. Cius is mentioned by early 3rd century $\mathrm{AD}$ in the Itinerarium Antonini Augusti 224.5, at a 10000 feet distance from Carsium (Hârșova) and another 14000 feet from Beroe (Piatra Frecăței). The milia passuum $X$ distance between Carsium and Cius could be checked with the aid of a milestone (ISM V, 96) set up in the time of Septimius Severus and C. Ovinius Tertullus, legatus Augusti pro praetore Moesiae Inferioris (AD 198-201).

The early Roman fortification, which likely quartered cohort I Lusitanorum Cyrenaica, until its movement upstream to Nigrinianis - later Candidiana (Malăk Preslavec), could not yet been identified in the field so far. Based on the epigraphic material, there may be established an existing rural area with a flourishing agriculture, clustered around two representative centres - Cius and Beroe - estimated to ca. $600 \mathrm{~km}^{2}$. This territorium was bordered in the south by the Topolog valley and to the north, by the Roștilor valley.

In the absence of systematic archaeological excavations of the site, two stone enclosures, both of late Roman date and unequal in sizes, were identified on the

\footnotetext{
11 POLONIC 1935, 18-26. TIR L 35, 33, 78 (for the subordinated vicus Vergobrittiani or vicus Vero[.] / [.]rittiani, according to a newer lecture, MATEI-POPESCU/FALILEYEV 2007; ZAHARIADE/GUDEA 1997, 79, no. 43; GUDEA 2005, 451, no. III. 43; BĂJENARU 2010, 128, no. 42; recently, a systematic discussion on the site, in OPRIȘ 2020, 5-18.
}

surface: the first measured approximately $120 \times 120 \mathrm{~m}$, while the smallest (within the largest) is approximately $85 \mathrm{x}$ $60 \mathrm{~m}$. Both fortifications are protected by a defensive system by ditch and rampart. The ancient tumular necropolis (uninvestigated up to now), likely of Roman date, was identified within the perimeter of the modern village of Gârliciu.

The largest fortification was built a fundamentis, similarly to most fortifications along the Lower Danube frontier, in the last decades of the 3rd - first decades of the 4th century, exhibiting features typical to the Tetrarchy/ Constantinian period. Lying in ruin, as reported by sources, it was hastily rebuilt at smaller sizes in AD 369, according to a Bauinschrift discovered at Gârliciu (CIL III, $6159=$ 7494 = IGLR, no. 233). We found, however, that this official inscription was originally removed by the village inhabitants from halfway the northern side of the smaller fortification, where it should have stood above the gate. Reconstruction works were carried out upon the orders of emperor Valens himself, placed under the supervision of Flavius Stercorius, an equestrian rank province governor (dux, vir clarissimus) and completed by milites primani headed by a tribunus Marcianus and a praepositus Ursicinus. The entire operation is accounted broadly by Themistios an oration delivered before the emperor at Constantinople in AD Jan./Feb. 370 (Or.

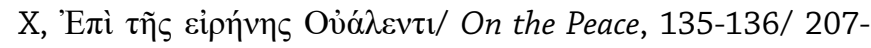
208; 137/208-209), while recent excavations, supported by mapping and high-resolution photogrammetry, confirmed the accuracy of the information and the specific details of the place supplied by the literary source. The late fortification was most definitely in function during the second half of the 4 th century $\mathrm{AD}$, being very likely encamped by cuneus equitum stablesianorum, a unit mentioned by Notitia Dignitatum (NDOr. XXXIX, 14) as being garrisoned in Moesia Secunda at Sucidava, however with detachments also present downstream, at Cius and Beroe.

There are no relevant archaeological data for the subsequent centuries, nonetheless the coin finds ${ }^{12}$ from Cius and the neighbouring area emphasized an intensive habitation starting from the Tetrarchy until the time of Honorius and Theodosius II, with a somewhat later rebound in the 5 th century $\mathrm{AD}$, once the period of the great Hunnic raids was surpassed ${ }^{13}$.

The fortifications' plan has been partially restituted based on drone collected data, field observations and consequent integration with P. Polonic's plans. It also meant retracing the enclosures and other inner buildings according to the trajectory of the stonewalls removal trenches in modern times. The lack of systematic excavations or for that matter of any other intrusive assessments, casts doubt on the fortification's function in the 5 th -6 th century AD. Until then, this castellum or possibly only the burgus of Valens must have been operating under the administrative authority of the great fortification at Carsium, nearby.

12 See OPRIȘ 2020, 15-16, n. 43; CHIRIAC/UNGUREANU 2004 (31 bronze coins between Aurelian and Valens; two lead seals, of which one from Smyrna, likely dated to the 4 th century AD).

${ }_{13}$ NICOLAE/NICOLAE 2006, 290, n. 96 (with the mention of a follis of Justin II and Sophia recovered from the bank break with archaeological depositions nearby the lake). 


\section{LUNCAVIȚA ${ }^{14}$}

The fortification of Luncavița (Fig. 12-15) is located on Milan Hill, on a rocky plateau with a $48 \mathrm{~m}$ elevation. It lies at $2.5 \mathrm{~km}$ north the village, access being made from a local road formed by the entry of road E 87 (DN22), in the north of Luncavița. The fortification's position provided in Antiquity co-visibility with the small fort at Rachelu, the latter located in straight line at ca $4.6 \mathrm{~km}$ eastwards, and easy communication, both by waterway but also along the high bank.

First records are made in Gr. Tocilescu's manuscripts, in the last years of the 19th century (Fig. 12). There is no information related to any archaeological excavations within the fortification's area or other additional data. No other mentions of a unit or clues on the ancient's name of the fortification are known. Now, while resuming discussion on the fortification, we argue that the fortification on Milan Hill was very likely operational during the 2 nd - 3rd century AD. The site was briefly referenced in synthesis works on the Roman frontier, in dictionaries or short notes on certain archaeological excavations in the respective area, yet concerning other historical periods or chance finds.

The detailed examination of the orthophoto plans, maps, satellite data and aerial photos resulted in a much more complex plan (Fig. 14-15). The outlines of the enclosure walls and some of the internal buildings may be observed with accuracy in the negatives of the wall removal trenches.

Thelong side runs on a roughly North East-South West direction and measures $237 \mathrm{~m}$ in length, while the shorter one, between $87 \mathrm{~m}$ (northern side) and $93 \mathrm{~m}$ (southern side). There are visible the rounded towers (or/and rather trapezium-shaped?; splayed fan-shaped?) of the southern side, corners included, and again possibly rectangular ones defending the east and west sides. Given the characteristics of the terrain, the planimetric distribution of the long sides must have required even more intermediary towers. The most visible is the south-western corner tower. Within the fortification are noticeable many traces of different buildings belonging to the final stage of occupation delimited by modern stone removal trenches.

In the 2018 and 2019 campaigns, during the documenting and monitoring process of the fortifications on the southern sector of the Roman frontier in Romania, we performed several field surveys and two series of drone flights, leading to the completion of the mapping documentation of Milan Hill and the Rachelu fortification (Fig. 16-17), the latter located within the territory of Luncavița commune as well. For a better understanding of the Roman defensive system details and adequate delimiting of settlements and military installations in this area, investigation was extended to an as large as possible area.

We rectified the plan of the fortification on Milan Hill after making enhanced resolution models. We also obtained additional details of the internal layout of the fortification and adjusted the layout of the enclosures by improved correlation with the plan drafted by Polonic. These overlapped

\footnotetext{
${ }_{14}$ POLONIC 1935, 24; TIR L 35, 35, 49; ȚENTEA 2015, 269-275; ȚENTEA 2018, 105-118.
}

data resulted in a clearer division of certain trenches, which on a number of stretches contain regular elements and structures resembling to WWI trenches. Similar trenches could be also identified in other Roman sites from northern Dobrudja, like those at Noviodunum or Salsovia.

\section{ISACCEA (NOVIODUNUM) ${ }^{15}$}

The site is located at "La Pontonul Vechi" (Cetate, Eski-kale), $2.5 \mathrm{~km}$ north-east the city of Isaccea, on the right Danube bank (Fig. 18-20).

In the fleet fort (Fig. 21-22), the main headquarters of classis Flavia Moesica, were identified many inscriptions, fleet stamps and stamps of legions V Macedonica and I Italica.

The civil settlement, very likely a civitas, becomes municipium Noviodunum sometime by early 3rd century AD, unless even earlier, during the joint reign of Marcus Aurelius and Commodus (177-180). Several inscriptions (spolia) reused in the walls of the late fortification at Halmyris record a vicus classicorum, a sailors`village. It is highly likely these were carried in fact from nearby Noviodunum, the stationing location of classis Flavia Moesica. In terms of the fortification's port, recent excavations (2016) conducted by the Bavarian Society for Underwater Archaeology in cooperation with the Eco-Museum Research Institute of Tulcea (ICEM) evidenced a deep channel running parallel to the Dobrudjan bank and the northern side of the fortification, on a distance of ca. 1.2 $\mathrm{km}$ upstream. Logically, the resulting hypothesis proposes that the location area of the port lay in the natural basin west of the ancient fortification (Pond Izet Efendi mentioned on the Military Map known as "Planul Director de Tragere"), currently sanded. ${ }^{16}$

The main seat of legion I Iovia Scythica (ND, Or. 39, 32-33; IGLR 266) and of an auxiliary unit, milites primi Constantiniani (ND, Or. 39, 25) was at Noviodunum during the Dominate. Archaeologically is known the late Roman fortification, trapezoid in shape, surrounded by several defensive ditches. Most of its northern enclosure is today under the Danube's waters. It survives underwater on approximately $200 \mathrm{~m}$ in length. Its curtain walls were $3 \mathrm{~m}$ thick and were also provided with 7 rounded (or "U"-shaped) interval towers. The southern enclosure is the most visible, with three towers revealed by excavation, one fan-shaped in its southern corner, one intermediary "U"-shaped, and that in the middle, a rectangular impressive size bastion (more than $35 \mathrm{~m}$ long and with four in a row supporting pillars of the internal suprastructure). In 2011, a new Early Christian basilica with a polygonal external facing of the apse (end of the 5th - 6th century AD) was identified on the Danube bank (extra muros), at cca $150 \mathrm{~m}$ east from the curtain walls, which may only be expected for a city where in the 6th century AD operated an Episcopal see.

The site is topped by the medieval fortifications of

\footnotetext{
15 TIR L 35, 53-54; STEFAN 1973, 3-14; SUCEVEANU 1977, 59-61, no. 3; BARNEA/BARNEA 1984, 97-105; SIMION et alii 1994-1995, 121-149; ZAHARIADE/GUDEA 1997, 81, no. 50; GUDEA 2005, 458, IV. no. 50; LOCKYEAR/SLY/POPESCU 2005-2006, 121-158; LOCKYEAR/POPESCU/ SLY 2007-2008, 45-48 STĂNICĂ et alii 2013, 72-73; TOPOLEANU et alii 2017, 70-72; MATEI-POPESCU 2016, 213 - 222.

${ }^{16}$ FIEDERLING/PÄFFGEN/PFLEDERER 2017.
} 
Isaccea, of which the most visible is the Ottoman one.

A complex project (The Noviodunum Archaeological Project) of survey, geophysical research and field walks targeting the defensive structure and inhabitancy in the city's civil settlement, which involved Kris Lockyear, Adrian Popescu, Timothy Sly (University College London, University of Cambridge University, University of Southampton) took place at Noviodunum between 2000-2004, 2005-2008, 20092011.

In this site we focused, alike in many other cases, on drafting a 3D photo model by processing the ortho and oblique pictures. We also studied in detail all available bibliography and mapping referring firstly to the defensive components, non-invasive approaches as well as ongoing excavations intra and extra muros at Noviodunum.

\section{TULCEA (AEGYSSUS) ${ }^{17}$}

The Roman fortification of Aegyssus lies in the northeastern area of Tulcea municipality, in the Park overtopped by the Independence Monument, on the so-called "Colnicul Hora”, or Hora-Hill. Currently, a number of late Roman date archaeological complexes may be visited. Many artefacts discovered over the course of the systematic excavations are housed in the permanent exhibition and deposits of the History and Archaeology Museum nearby (Fig. 23-25).

During the Principate, when mentioned in It.Ant. $(226,2)$, an auxiliary fort was very likely in function there, able to accommodate a statio classis. The archaeological excavations yielded stamps of cohort II Flavia Brittonum, respectively classis Flavia Moesica. In the 4th-5th century $\mathrm{AD}$, Aegyssus becomes the garrison of a cuneus equitum armigerorum and especially the seat of a praefectus ripae legionis I Ioviae cohortis $V$ pedaturae inferioris, according to the mentions in $N D, O r ., 29,17,34$. Later, in the 6th century AD, Aegyssus appears mentioned among the 15 top fortifications of the province of Scythia (Hierocles, Synecdemus, 637, 14), also Episcopal residence at the time.

The settlement was strongly fortified by the end of the 3rd or in the early 4th century in order to serve the strategic role it was awarded for the defence of the Danubian frontier (seat of the pedatura inferior defended by 5 cohorts from legio I Iovia Scythica). It was rebuilt under Justinian (Procopius, De aedif., IV, 7, 20), in continuance of the large scale re-fortification process initiated under Anastasius. Three different building phases were identified for the enclosure wall and related towers, the settlement being deserted by the end of the 6th century or more likely by early 7 th century (latest coin is dated 613/614, from the reign of Heraclius) ${ }^{18}$. It was then remade starting with the comeback of the Byzantines to the Lower Danube by the end of the 10th century. The archaeological excavations revealed 7 towers ( 2 presumed), outlining buildings built in the $3 r d, 4$ th respectively 6 th century AD.

\footnotetext{
17 TIR L 35, 21-22; OPAIT 1977, 307-311 (Fig. 2); SUCEVEANU 1977, 58 59, no. 2; ZAHARIADE/GUDEA 1997, 81-82, no. 52; GUDEA 2005, 460, no. IV. 52; ZAHARIADE/COVACEF/LUNGU 2006, 92-93; NICOLAE 2013, 167-168.

18 OBERLÄNDER-TÂRNOVEANU 1980, 163.
}

The archaeological research at Aegyssus was resumed in 2015, in the south-eastern side of the site, where between 1971-1997/1998 had been identified and investigated a bath complex and a possible palestra, streets and a granary (horreum), complexes dated broadly between the 2 nd century - first half of the 5 th century AD. Recent archaeological excavations conducted by the Eco-Museum Research Institute of Tulcea (ICEM) together with the Institut für Vor- und Frühgeschichtliche Archäologie und Provinzialrömische Archäologie - Universität LudwigMaximilian, München also included new methodological approaches: photogrammetry, aerial photogrammetry, magnetometry and $3 \mathrm{D}$ restitution ${ }^{19}$.

\section{MIRCEA VODĂ}

The fortification lies at ca $3.5 \mathrm{~km}$ east the train station of Mircea Vodă village and the homonym commune, at ca $1-1.3 \mathrm{~km}$ south-east the latter, on a rocky promontory verging national road DN 22C (Fig. 26-27), on the "La Talieni" site. The quadriburgium ( $50 \times 50 \mathrm{~m}$ ), likely built under the Tetrarchy, with rounded towers, seems to have functioned in the 4 th -5 th century AD. It was destroyed in most part by a stone quarry, however, ot its eastern side are still noticeable the foundations of a circular tower, with an approximate diameter of 3.5 meters. Field surveys and site mapping were carried out by drone scanning ${ }^{20}$.

Constructionally, its specificity resides in the wall facings made in a "Binder-Läufer" system, the enclosure wall being ca $1.50 \mathrm{~m}$ thick. For the lack of proper research, it remains unclear whether the fortification was indeed square in shape (50 x $50 \mathrm{~m}$ ) or almost trapezium-shaped (50 x 30 m), as originally believed by Eugen Comșa, in 1951-1952 ${ }^{21}$. The plan reconstructed according to digital terrain model provided us a rhomboid shape, similar to that of the Roman fort at Traian village ${ }^{22}$ (Fig. 27). The pottery collected from around the south-eastern tower (damaged by soil erosion and recent anthropic interference) suggests a broad dating to the 4 th -5 th century AD; in addition, from Mircea Vodă is also known a coin hoard whose pieces end under Leon I $(457-474) .^{23}$

The fortification controlled in the late Roman period the road connection between Tomis and Axiopolis, by the crossroads with the Central-Dobrudjan road (Tropaeum Traiani - Ulmetum - Noviodunum). Highly valuable information is provided by the map of the Kara-su valley by the British captain Thomas A.B. Spratt, published by the end of the Crimean War (1856) in the Journal of the Royal Geographical Society of London ${ }^{24}$. The detailed map (Fig. 28)

\footnotetext{
9 PÄFFGEN/NUȚU et alii 2017.

20 TIR L 35, 51; COMȘA 1957; ȘTEFAN 1974, 107-108, Fig. 4; BĂJENARU 2010, 154, no. 91, 325 Pl. 95; TALMAȚCHI/TALMAȚCHI/ȘOVA/ VASILESCU/ANDREI, Studiu istoric aferent PUG-ului comunei Mircea Vodă, Județul Constanța, 2015: http://ran.cimec.ro/sel.asp?descript=mirceavoda-mircea-voda-constanta-asezarea-intarita-de-la-mircea-voda-valeacarasu-cod-sit-ran-62299.04

${ }^{21}$ COMȘA 1957, 325, 326 = Fig. 1, 2. Accordingly, the short side is that southern.

22 T,ENTEA et alii 2019, 39-41, Fig. 11.1-11.4.

23 CUSTUREA/TALMAȚCHI 2011, 272-273.

24 SPRATT 1856. See Maps from the Journal of the Royal Geographical Society of London, Volume 26, 1856. Sketch of the country between Kustenje
} 
of the valley and lakes stringing from west to east evidences the strategic location of this minor fortification, controlling the westward crossing (in front the current train station at Mircea Vodă), respectively that eastwards Mircea Vodă (Chilibe Keui/ Celibichioi). The latter stood, according to the said map, in front the place of today's Satu Nou village. The comments accompanying the map by mid 19th century mentioned a distance of 10-11 miles from the headland located westward Mircea Vodă (current train station) to the flow into the Danube, as well as possibility of navigation after dredging and excavation works, provided previous landscaping was carried out ${ }^{25}$.

\section{MIHAI BRAVU}

The fortification (Fig. 29-31) is situated at an approximately $7 \mathrm{~km}$ north-west distance from Topraichioi, by the border of the Mihai Bravu village (near county road DJ 229, on the left side, heading towards Turda village). The quadriburgium built on the Taița valley is $37 \times 37 \mathrm{~m}$ and has fan-shaped corner towers. This minor fortification $(0.10 \mathrm{ha})$ seems to have been erected sometime during the rule of emperor Constantine the Great and his sons (AD 308/311$340-350$ ), functioning exclusively in the 4 th century AD, until around the disaster of Adrianople (ca. AD 375-378), as available numismatic evidence seems to indicate. ${ }^{26}$

Mentioned for the first time by K. Škorpil during WWI (1917), the fortification was fully investigated by Andrei Opaiț (1987-1990), in the perimeter of a vicus Bad... (according to a local inscription reused in the facings of the Constantinian fortification). The vicus stretched on either side of county road DJ 229 and is one of the largest rural settlements of the Principate known in Dobrudja insofar (ca. $800 \times 800 \mathrm{~m})^{27}$. The epigraphic analysis of several limestone spolia (13) recovered from the facings of the 4th century quadriburgium (Fig. 29) evidences an existing strong Roman community - conventus of veterani et cives Romani consistentes vico Bad[---], a statio of beneficiaries in the last decade of the 2 nd century AD and the presence of T. Caelius Catus, beneficiarius consularis, yet also of a temple built for Iupiter Optimus Maximus Dolichenus, sometime under the Severans by the end of the 2nd - early 3rd century $\mathrm{AD}^{28}$. Numismatic records trace the existence of this flourishing vicus until the beginning of the subsequent century (Fig. 30 ), when the quadriburgium would be built. It is noteworthy that from there also comes the oldest military diploma known to date for Roman Dobrudja (dated to April 5, 71) ${ }^{29}$. Even this simple fact provides an image of the early settlers, consistency and scale of the local community.

and Chernavoda, showing the Kara-su Lakes, Capt. Spratt, 1856. Accessible online, in the University of Texas in Austin/ University of Texas Libraries, http://legacy.lib.utexas.edu/maps/historical/journal_of_royal_geographical_ society/txu-pclmaps-oclc-1774106-26-1856-sketch-of-the-country-betweenkustenje-and-chernavoda.jpg collection.

25 SPRATT 1856, 207-208. See online https://archive.org/details/ jstor-1798356/page/n9/mode/2up

${ }^{26}$ OPAIȚ et alii 1991, 192, n. 1; OPAIȚ 2004, 109; BĂJENARU 2010, 154 (No. 90), 171-172, 184-185.

27 OPAIȚ et alii 1992, Taf. 20, Abb. 8.

28 OPAIȚ et alii 1992, 107.

CHIRIAC/MIHĂILESCU-BÎRLIBA/MATEI 2004; PETOLESCU/ POPESCU 2007.
Upstream the Taița valley, the quadriburgium from Mihai Bravu frames into a road and defensive system linking the great fortresses of Ibida, Troesmis and Noviodunum, to which also belong other minor fortifications (Cerna, Izvoarele or Niculiţel) or horrea (at Enisala, Babadag and Horia).

A rectangular fortification is visible on satellite photos (Fig. 29.b) at approximately 350-400 m north of Satu Nou village and ca. $2 \mathrm{~km}$ east the quadriburgium of Mihai Bravu. The corners of the rectangular structure are oriented on the direction of the four cardinal points, while the structure's sides measure approximately 280 x $280 \mathrm{~m}$.

\section{CETATEA (FORMER AZARLÂK, DOBROMIR COMMUNE)}

The settlement is located by all accounts in the village centre, in the area of the Turkish fountain ${ }^{30}$ and the church dedicated to the Dormition of Virgin Mary and Saint Demetrius, around which many large limestone roughed-out blocks were found. There may be hypothetically located the civitas Ausdecensium (CIL III 14437, 2 = ISM IV 82), according to a famous inscription, which accounts how Anternius Antoninus, tribunus cohortis I Cilicum conducted the delimiting operations of the local territory from that of the nearby Dacians. The territorial conflict was thus concluded between AD 176-177, when legatus Augusti pro praetore Moesiae Inferioris was future emperor Helvius Pertinax. ${ }^{31}$

There is brief information surviving from early 20th century, when Jakob Weiss visited this isolate place. Without yet locating any ancient ensembles, he still reminds the existence of pieces chronologically stretching between the end of the 1 st century - 4th century AD. ${ }^{32}$ The numismatic evidence collected over the course of time, mostly clustered in the area nearby the local school further emphasizes such dating, namely the late Roman and Romano-Byzantine periods. ${ }^{33}$ The most recent coin is a bronze piece minted by the end of the reign of Justinian I at Thessaloniki. ${ }^{34}$

From the natives we found that the habitation and

\footnotetext{
30 BĂRBULESCU 2001 125 , n. 994. There (at the "çeşme" / local fountain, in Turkish), Gh. Papuc identified an ancient aqueduct remade by the natives, while nearby, at ca. 50-60 m distance, he further reported brick walls and Roman date pottery fragments.

31 MATEI-POPESCU 2010, 202.

32 WEISS 1911, 80: “... Sie stammten aus der Periode von Domitian bis Justinian, besonders häufig waren solche aus konstantinischer Zeit. Es scheint hier ein römisches "Praesidium", ein Kastell zur Sicherung der von Süden her über Abtaat-Kalessi nach Adamklissi-Tropaeum und Axiopolis führenden Strasse gewesen zu sein...."

33 At Cetatea, a bronze coin issued under Valens (364-365) was already known from a 1971 fieldwalk, see OCHEȘEANU/PAPUC 1973, 370 (no. 189). Other coin finds further underline the site's importance. The most consistent lot was discovered clustered especially nearby the local school, at a ca. $30 \mathrm{~m}$ distance, and contains no less than 48 pieces (no. 5-62), chronologically stringing from Licinius I (313-317) and Theodosius II/ Valentinian III (425-450), with the largest amassment under Constantine I and his sons (no. 10-47), see POPEEA 1980. See also CUSTUREA/VERTAN/TALMAȚCHI 1998, 317, no. 1847 1848 (Numerianus and Constantius II/ Constans, a. 346-350); CUSTUREA/ VERTAN/TALMAȚCHI 1999, 351, no. 2015-2016 (Maximianus and Licinius, a. 295/296, respectively a. 321-324); PETAC/IONESCU 2004-2009, 208-211 (a. 313-317); PETAC/IONESCU 2002, 109-111 (no. 2-18, between Licinius I, a. 313 and Justinian I, see infra). For all this information we thank our colleague Dan Vasilescu (MINA Constanța).

${ }^{34}$ PETAC/IONESCU 2002, 110 (no. 18, Justinian I, a. 562-563).
} 
cemetery area would stretch in the northern side of the village. Field surveys and site mapping were carried out by drone scanning ${ }^{35}$. A field walk in the summer of 2020 at Cetatea checked the plateau on Hisarlâk hill (Fig. 32) of ca 1.8. ha, just west the current village ${ }^{36}$, identifying exclusively specific „Dridu” or „Balkan-Danubian culture” pottery fragments, and apparently it isn 't the only reason for which the fortification briefly investigated by a team of the museum based in Constanța by early '70ies may be rather dated sometime during the 8 th -10 th century $\mathrm{AD}^{37}$. Several objects in bronze, among which also 4th century coins dated from Constantine the Great to Valentinian I, Valens or Gratian were purchased in the occasion from the native inhabitants (and later sent to MINA Constanța) ${ }^{38}$.

Civitas Ausdecensium lay during Antiquity on the route of the imperial road starting from Marcianopolis (Devnja, Bulgaria), running through Zaldapa (Abrit) - Cetatea (Civitas Ausdecensium?), Tropaeum Traiani (Adamclisi) - Mircea Vodă - Pantelimonul de Sus (Ulmetum) - Slava Rusă (Ibida) and Mihai Bravu, reaching the northern frontier of the province of Scythia, at Noviodunum (Isaccea) ${ }^{39}$.

\section{REFERENCES}

\section{Corpora}

CIL III

Mommsen, Th., Corpus Inscriptionum Latinarum. III. Inscriptiones Asiae provinciarum Europae Graecarum Illyrici Latinae, I-II (Berlin: Berolini apud Georgium Reimerum, 1873); O. Hirschfeld, A. von Domaszewski, Corpus Inscriptionum Latinarum, III. Supplementum, I-II (Berlin: Berolini apud Georgium Reimerum, 1902).

IGLR

Popescu, Em., Inscripţiile greceşti şi latine din secolele IV-XIII descoperite în România (Bucharest: Editura Academiei RSR, 1976).

ISM IV

Popescu, Em., Inscriptiones Scythiae Minoris, IV: TropaeumDurostorum-Axiopolis (Bucharest-Paris: Editura Academiei Române/ Editura Basilica/ Diffusion de Boccard, 2015).

${ }_{35}$ DID II, 164-165; TIR L 35, 24; BĂRBULESCU 2001, 125-126, 193, 215-216; MATEI-POPESCU 2010, 202-203; BÂLTÂC 2011, 86; OLTEAN/HANSON 2013, 326.

36 Ioan Opriș (University of Bucharest), Florian Matei-Popescu (Institute of Archaeology of the Romanian Academy in Bucharest), Dominic Moreau (Université de Lille) and Radu Petcu (MINAConstanța/ Université de Lille).

37 The only piece of information about the excavations conducted by MINA Constanța and Radu Ocheșeanu in the early '1970ies is that on that occasion were identified an early medieval earthen rampart (gradishte) and Saltovo type finds: POENARU-BORDEA 1998-2003, 488.

${ }_{38}$ Of the 6 pieces obtained in 2020, 5 have been already identified by Dan Vasilescu (MINAConstanța), whom we thank for this information. These are: 1. Constantine I; Arelate workshop; denomination AE3; type SOLI INVICTO COMITI; catalogue RIC, VII, 249, no. 145; AD 317-318; 2. Constantine I; Heraclea, Nicomedia or Cyzicus workshops; denomination AE3; type IOVI CONSERVATORI; catalogue RIC, VII, 548, no. 51 or 607 , no. 43 or 645 , no. 14; AD 321-324; 3. Constantine I; Constantinopolis workshop; denomination AE3; type GLORIA EXERCITVS (2ST); catalogue RIC, VII, 581, no. 73; AD 333-335; 4. Constantius II; Constantinopolis workshop; denomination AE3; type FEL TEMP REPARATIO (FH3); catalogue RIC, VIII, 458, no. 121; $\mathrm{AD}$ 353/4-355; 5. Valentinian I, Valens or Gratian; Alexandria workshop; denomination AE3; type SECVRITAS REI PVBLICAE; catalogue cf. RIC, IX, 298, no. 3(a), general type or 299, no. 5(a), general type; AD 364-375.

39 BĂJENARU 2010, 30; PANAITE/MIU (BEM) 2016, 208.
ISM V

Doruțiu-Boilă, Em., Inscriptiones Scythiae Minoris, V: Capidava- Troesmis-Noviodunum (Bucharest: Editura Academiei RSR, 1980).

\section{TIR L 35}

Russu, I. I./Gostar, N./Ivanov, T./Popescu, Em./Protase, D./ Tudor, D., Tabula Imperii Romani. Romula - Durostorum Tomis. L 35 Bucarest (Bucharest: Academie de la République Socialiste de Roumanie, 1969).

\section{Works}

\section{BARNEA/BARNEA 1984}

Barnea, I./Barnea, Al., Săpăturile de salvare de la Noviodunum, Peuce 9, 97-105.

\section{BĂJENARU 2010}

Băjenaru, C., Minor Fortifications in the Balkan-Danubian Area from Diocletian to Justinian. The Center for Roman Military Studies 8 (Cluj-Napoca: Mega Publishing House).

\section{BĂRBULESCU 2001}

Bărbulescu, M., Viața rurală în Dobrogea romană (sec. I-III p.Chr.). Bibliotheca Tomitana III (Constanța: Muzeul de Istorie Națională și Arheologie Constanța).

\section{BÂLTÂC 2011}

Bâltâc, Adela, Lumea rurală în provinciile Moesia Inferior și Thracia (secolele I-III p.Chr.), Muzeul Național de Istorie a României - Monografii VI (Bucharest: Renaissance).

\section{COMȘA 1957}

Comșa, E., Câteva descoperiri arheologice din raionul Medgidia (regiunea Constanţa), Materiale și cercetări arheologice 4, 325-334.

\section{CHIRIAC/MIHĂILESCU-BÎRLIBA/MATEI 2004}

Chiriac, C./Mihăilescu-Bîrliba, L./Matei, I., Ein neues Militärdiplom aus Moesien, Zeitschrift für Papyrologie und Epigraphik 150, 265-269.

\section{CHIRIAC/UNGUREANU 2004}

Chiriac, C./Ungureanu, C., Cius - New Roman finds on the Danubian Limes in Scythia (Dobrudja), Arheologia Moldovei 27, 233-239.

\section{CUSTUREA/TALMAȚCHI 2011}

Custurea, G./Talmațchi, G., Repertoriul tezaurelor monetare din Dobrogea (Bibliotheca Tomitana 7) (Constanța: Ex Ponto).

\section{CUSTUREA/VERTAN/TALMAȚCHI 1998}

Custurea, G./Vertan, A./Talmațchi, G., Descoperiri monetare în Dobrogea (12), Pontica 31, 309-328.

\section{CUSTUREA/VERTAN/TALMAȚCHI 1999}

Custurea, G/Vertan, A./Talmațchi, G., Descoperiri monetare în Dobrogea (13), Pontica 32, 347-365.

\section{FIEDERLING/PÄFFGEN/PFLEDERER 2017}

Fiederling, M./Päffgen, B./Pflederer, T., Noviodunum - die Suche nach dem Hafen. Eine Alte Frage und Neue Forschungen unter Einsatz von Modernen Unterwasserarchäologischen Prospektionsmethoden. In: Nuțu, G./Ailincăi, S.-C./Micu, C. (eds.), Omul, fluvial și Marea. Studii de arheologie și istorie în onoarea lui Florin Topoleanu la a 65-a aniversare (Cluj-Napoca: Mega Publishing House), 287-300.

\section{FLORESCU 1924}

Florescu, Gr., Noi descoperiri epigrafice la Seimenii Mari, Buletinul Comisiunii Monumentelor Istorice 17, fasc. 40, 88-90.

\section{GUDEA 2005}

Gudea, N., Der untermoesische Donaulimes und die Verteidigung der moesischen Nord- und Westküste des 
Schwarzen Meeres. Limes et Litus Moesiae inferioris (86-275 n. Chr.), Sonderdruck aus Jahrbuch des RömischGermanischen Zentralmuseums Mainz 52, 319-566.

IRIMIA 1980

Irimia, M., Date noi privind aşezările getice din Dobrogea în a doua epocă a fierului, Pontica 13, 66-116.

LOCKYEAR/SLY/POPESCU 2005-2006

Lockyear, K./Sly, T./Popescu, A., The Noviodunum Archaeological Project 2000-2004: Results and conclusion from the pilot seasons, Peuce (s.n.) 3-4, 121-158.

LOCKYEAR/POPESCU/SLY 2007-2008

Lockyear, K./Popescu, A./Sly, T., Rome and Byzantium on the Danube: The Noviodunum Archaeological project 20052008, Archaeology International 11, 45-48.

MATEI-POPESCU 2010

Matei-Popescu, Fl., The Roman Army in Moesia Inferior. The Center for Roman Military Studies 7 (Bucharest: Conphys Publishing House)

MATEI-POPESCU 2016

Matei-Popescu, Fl., Vicus Nov(iodunum) and vicus classicorum: On the origins of the municipium Noviodunum. In: Ancient West and East 15. Volume dedicated to Professor Alexandru Avram to celebrate his 60th birthday, 213-222.

MATEI-POPESCU/FALILEYEV 2007

Matei-Popescu, Fl./Falileyev, Al., Notă asupra ISM V, 115, Tyragetia (s.n.) I [16], nr. 1, 323-326.

MIHĂILESCU-BÎRLIBA/IBBA 2020

Mihăilescu-Bîrliba, L./Ibba, A., Vicus Bad [---]: la contribution de l'épigraphie à la reconstruction du tissu socio-culturel d'un village de la Moesia Inferior (Ier-IIIe siècle ap. J.-C.). In: Mitthof, F./Cenati, C./Zerbini, L. (eds.), Ad ripam fluminis Danuvi. Papers of the 3rd International Conference on the Roman Danubian Provinces, Vienna, 11th-14th November 2015, Tyche Suppl. (Vienna: Holzhausen Verlag GmbH) (forthcoming).

NICOLAE 2013

Nicolae, C., Dunărea de Jos și nordul pontic. Interferente istorice (cu privire specială în secolele IV-VII) (Bibliotheca Tomitana 10) (Bucuresti: TOP FORM) NICOLAE/NICOLAE 2006

Nicolae, C./Nicolae, Vl., Vadul Dunării de la Hârșova și rolul său în epoca romană și romano-bizantină, Pontica 39, 279-291.

OBERLÄNDER-TÂRNOVEANU 1980

Oberländer-Târnoveanu, E., Monede bizantine din secolele VII-X descoperite în nordul Dobrogei, Studii şi Cercetări de Numismatică 7, 163-165.

OCHEȘEANU/PAPUC 1973

Ocheșeanu, R./Papuc, Gh., Monede grecești, romane și bizantine descoperite în Dobrogea (II), Pontica 6, 351-381.

OLTEAN/HANSON 2013

Oltean, I./Hanson, W. S., Integrating aerial satellite imagery: discovering Roman imperial landscapes in Southern Dobrudja (Romania). In: Hanson, W. S./Oltean, I. (eds.), Archaeology from historical aerial and satellite archives (New York: Springer), 315-336.

OPAIT 1977

Opaiț, A., Aegyssus '76 - Raport preliminar, Pontica 10, 307-311.

OPAIT et alii 1991

Opaiţ, A./Zahariade, M./Poenaru-Bordea, Gh./Opaiţ, Cr., Fortificaţia și așezarea romană târzie de la BabadagTopraichioi, Peuce 10, 1, 183-353 (text); 2, 217-310 (illustration).
OPAIŢ et alii 1992

Opaiţ, A./Opaiţ, Cr./Bănică, T., Das ländliche Territorium der Stadt Ibida (2.-7. Jh.) und einige Betrachtungen zum Leben auf dem Land an der Unteren Donau. In: Pillinger, R./Pülz, A./Vetters, H. (eds.), Die Schwarzmeerkuste in der Spätantike und im frühen Mittelalter, Schriften der BalkanKommission, antiquarische Abteilung (Vienna: VÖAW), 103-112.

OPAIȚ 2004

Opait, A., Local and Imported Ceramics in the Roman Province of Scythia (4th - 6th centuries AD). Aspects of Economic Life in the Province of Scythia, [British archaeological reports. International series 1274] (Oxford: Archaeopress).

OPRIȘ/DOBRINESCU 2018

Opris, I. C./Dobrinescu, C., Cetatea romană de la Stânca Topalu - cariera "Margela" (sau "Mariella"). Dosarul arheologic pentru o meritată reparație istorică, Cercetări arheologice 25, 181-204.

OPRIȘ 2019

Opriș, I. C., Ab Axiupoli VI milia passuum. Cetatea romană de la Seimenii Mari. In: Avram, Al./Buzoianu, L. (eds.), Varia epigraphica et archaeologica. Volume dédié à la mémoire de Maria Bărbulescu, Pontica 52, Supplementum 6, 271-290.

OPRIȘ 2020

Opriș, I. C., Rediscovering roman Cius (Gârliciu, Constanța county, Romania). From Emperor Valens to Grigore Tocilescu, Theodor Mommsen and beyond, Journal of Ancient History and Archaeology 7/1, 5-18. DOI: 10.14795/j. v7i1.514

PANAITE/MIU (BEM) 2016

Panaite, A./Miu (Bem), C., Roman roads identified on aerial and satellite images within the territory of the city of Tropaeum Traiani (Moesia Inferior), Dacia N.S. 60, 201220.

PÄFFGEN/NUȚU et alii 2017

Päffgen, B./ Nuțu, G. (in Zusammenarbeit mit Anton, Daniel, Hölzl, Mario, Rinser, Florian, Scharafin-Hölzl, Ursula, Scheiblecker, Marion, Schauer, Michaela), Neue Prospektionsmethoden im antiken Aegyssus. In: Nuțu, G./ Ailincăi, S.-C./Micu, C. (eds.), Omul, fluvial și Marea. Studii de arheologie și istorie in onoarea lui Florin Topoleanu la a 65-a aniversare (Cluj-Napoca: Mega Publishing House), 275-286.

PÂRVAN 1914

Pârvan, V., Archäologische Funde im Jahre 1913. Rumänien, Archäologischer Anzeiger. Jahrbuch des Kaiserlich Deutschen Archäologischen Instituts 29, col. 430-431.

PETAC/IONESCU 2002

Petac, Em./Ionescu, M., Descoperiri de monede romane imperiale si bizantine din Dobrogea. In: Simpozion de numismatică (organizat în memoria martirilor căzuți la Valea Albă, la împlinirea a 525 ani (1476-2001), Chișinău, 13-15 mai 2001) (Bucharest: Ed. Enciclopedică), 109-111.

PETAC/IONESCU 2004-2009

Petac, Em./Ionescu, M, O monedă alexandrină a lui Aurelius Valerius Valens descoperită la Cetatea, com. Dobromir, jud. Constanța, Buletinul Societății Numismatice din România 98-103, 208-211.

PETOLESCU/POPESCU 2007

Petolescu, C. C./Popescu, A.-T., Trois fragments de diplômes militaires de Dobroudja, Dacia N. S. 51, 147-151.

POENARU-BORDEA 1998-2003

Poenaru-Bordea, Gh., Radu Ocheseanu (1943-1998), Buletinul Societății Numismatice din România 92-97, 487-495. 


\section{POLONIC 1935}

Polonic, P., Cetățile antice de pe malul drept al Dunării (Dobrogea) până la gurile ei, Natura. Revistă pentru răspândirea științei 24/7 (15 iulie), 18-26.

\section{POPEEA 1980}

Popeea, Al., Monede romane tîrzii descoperite în sudul Dobrogei, Studii şi Cercetări de Numismatică 7, 155-160.

\section{SPRATT 1856}

Spratt, Th. A. B., Route between Kustenjé and the Danube by the Kara-su and Yeni-Keui Valleys, with Observations on the Navigation of the Kara-su Lakes and Their Origin; Also on the Requirements Necessary to Render the Water and Land Communication Practicable; Being the Result of an Examination Made during a Recent Journey with Lieut.-Col. Hon. A. Gordon and Lieut.-Col. J. Desaint, de l'Etat Major, The Journal of the Royal Geographical Society of London 26, 203-210.

STĂNIC̆ et alii 2013

Stănică, A./Topoleanu, Fl./Bilavschi, G./Adamescu, A., Noviodunum. Bazilica 2, Cronica cercetărilor arheologice din România. Campania 2012 (Iași: Editura Universității Alexandru Ioan Cuza, Institutul Național al Patrimoniului), 72-73.

SUCEVEANU 1977

Suceveanu, Al., Viaţa economică în Dobrogea romană (secolele I-III e.n), Biblioteca de Arheologie 28 (București: Editura Academiei RSR).

SUCEVEANU/BARNEA 1991

Suceveanu, Al./Barnea Al., La Dobroudja romaine (Suceveanu, Al., La Dobroudja aux I ${ }^{\text {er-III }}$ siècles n. è., 22153; Barnea, Al., La Dobroudja aux IVe-VII e siècles n. è., 154-317) (Bucarest: Editura Enciclopedică).

SIMION 1994-1995

Simion, G. et alii, Ensemble funéraire de la nécropole tumulaire de Noviodunum (Isaccea), Dacia N. S. 38-39, 121149.

ȘTEFAN 1973

Ștefan, Al. S., Noviodunum. Studiu de foto-interpretare arheologică, Buletinul Monumentelor Istorice 42/1, 3-14.

\section{STEFAN 1974}

Ștefan, Al. S., Recherches de photo-interpretation archeologique sur le limes de la Scythie Mineure a l 'epoque du Bas-Empire. In:Actes du IXe Congrès International d'Etudes sur les Frontières Romaines, Mamaia 1972 (Bucarest-KölnWien), 95-108, Pl. 16-23.

\section{TOCILESCU 1887}

Tocilescu, Gr., Neue Inschriften aus der Dobrudscha, Archäologisch-epigraphische Mitteilungen aus ÖsterreichUngarn 11, Heft I, 19-70.

TOPOLEANU et alii 2017

Topoleanu, Fl./Stănică, A./Mocanu, M./Nuțu, G./ Ionescu-Preotu, C./Eftimie, D./Pascu, M./Drăgan, A., Noviodunum Bazilica 2, Cronica cercetărilor arheologice din România. Campania 2016 (București: Institutul Național al Patrimoniului), 70-72 (http://cimec.ro/Arheologie.html).

\section{TORBATOV 2002}

Torbatov, S., Ukrepitelnata sistema na provincija Skitija (kraja na III - VII v.)/ The defence system of the Late Roman Province of Scythia (end of the 3rd - 7th century A.D.) (V. Tărnovo: Faber).

T,ENTEA 2015

Țentea, O., Closing a gap. A roman fort rediscovered. In: Vagalinski, L./Sharankov, N. (eds.), Limes XXII. Proceedings of the XXIIth International Congress of Roman Frontier Studies, Ruse, Bulgaria, September 2012 (= Bulletin of the National Archaeological Institute 42), 269-275.

\section{ȚENTEA 2018}

Tentea, O., Un segment de limes redescoperit: Luncaviţa, jud. Tulcea / A rediscovered section of the limes: Luncaviţa, Tulcea County, Cercetări arheologice 25, 105-118.

\section{T,ENTEA et alii 2020}

Țentea, O./Opriș, I. C./Matei-Popescu, Fl./Rațiu, Al./ Băjenaru, C./Călina, V., Frontiera romană din Dobrogea. O trecere în revistă și o actualizare, Cercetări arheologice 26, 9-82.

\section{WEISS 1911}

Weiss, Jakob, Die Dobrudscha im Altertum. Historische Landschaftskunde, coll. Zur Kunde der Balkanhalbinsel Heft 12, Reisen und Beobachtungen (Sarajevo: D.A. Kajon).

\section{ZAHARIADE 1999}

Zahariade, M., The Roman Frontier in Scythia Minor (1980-1995). In: Gudea, N. (ed.), Proceedings of the XVIIth International Congress of Roman Frontier Studies, Zalău 1997 (Zalău: Publishing House Porolissum), 199-213.

\section{ZAHARIADE/GUDEA 1997}

Zahariade, M./Gudea, N., The Fortifications of Lower Moesia (AD 86-275) (Amsterdam: A. M. Hakkert).

\section{ZAHARIADE/COVACEF/LUNGU 2006}

Zahariade, M./Covacef, Z./Lungu, V., Scythia Minor. A History of a Later Roman Province (284-681), Pontic Provinces of the Later Roman Empire 1 (Amsterdam: A. M. Hakkert). 


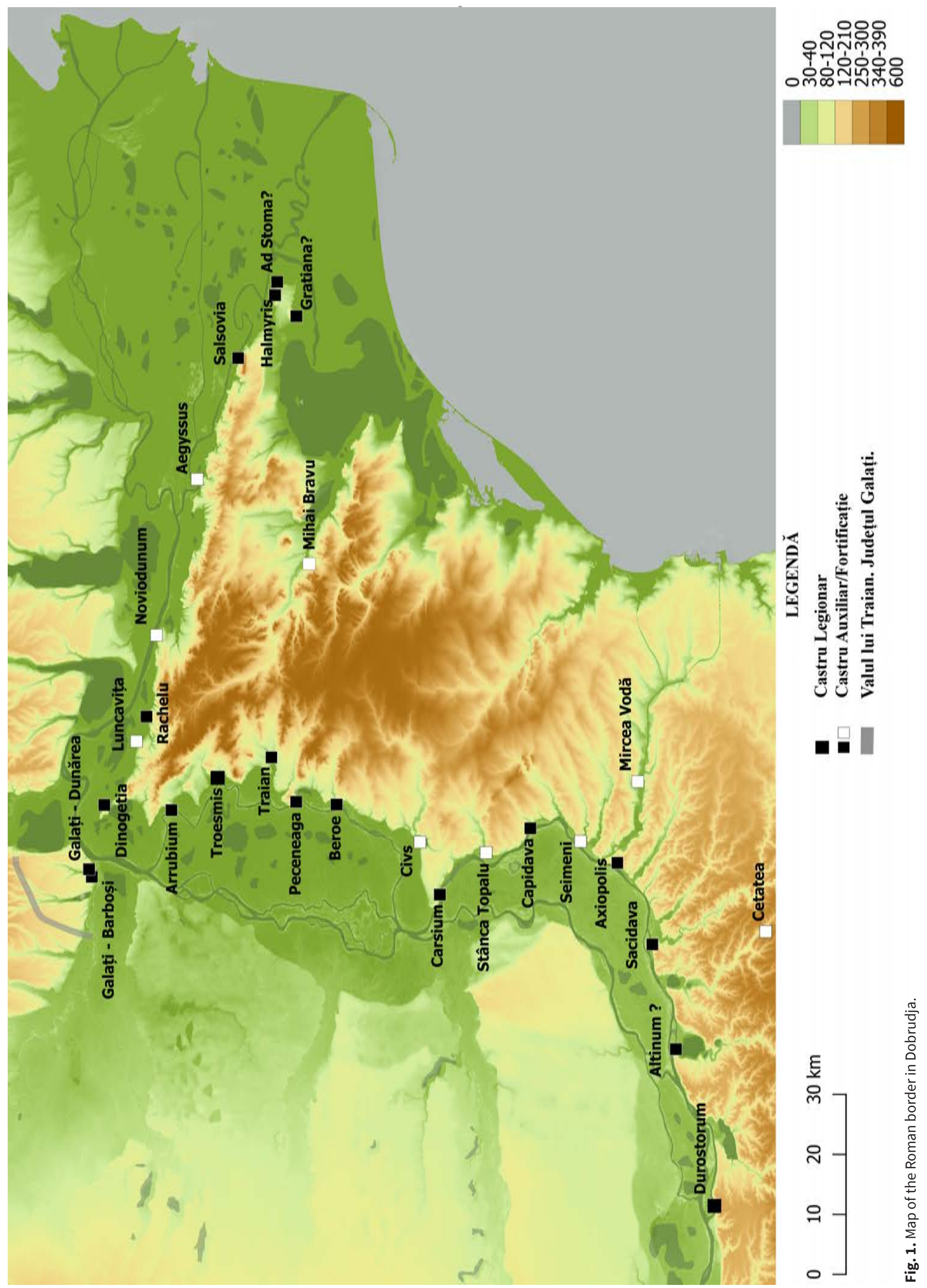




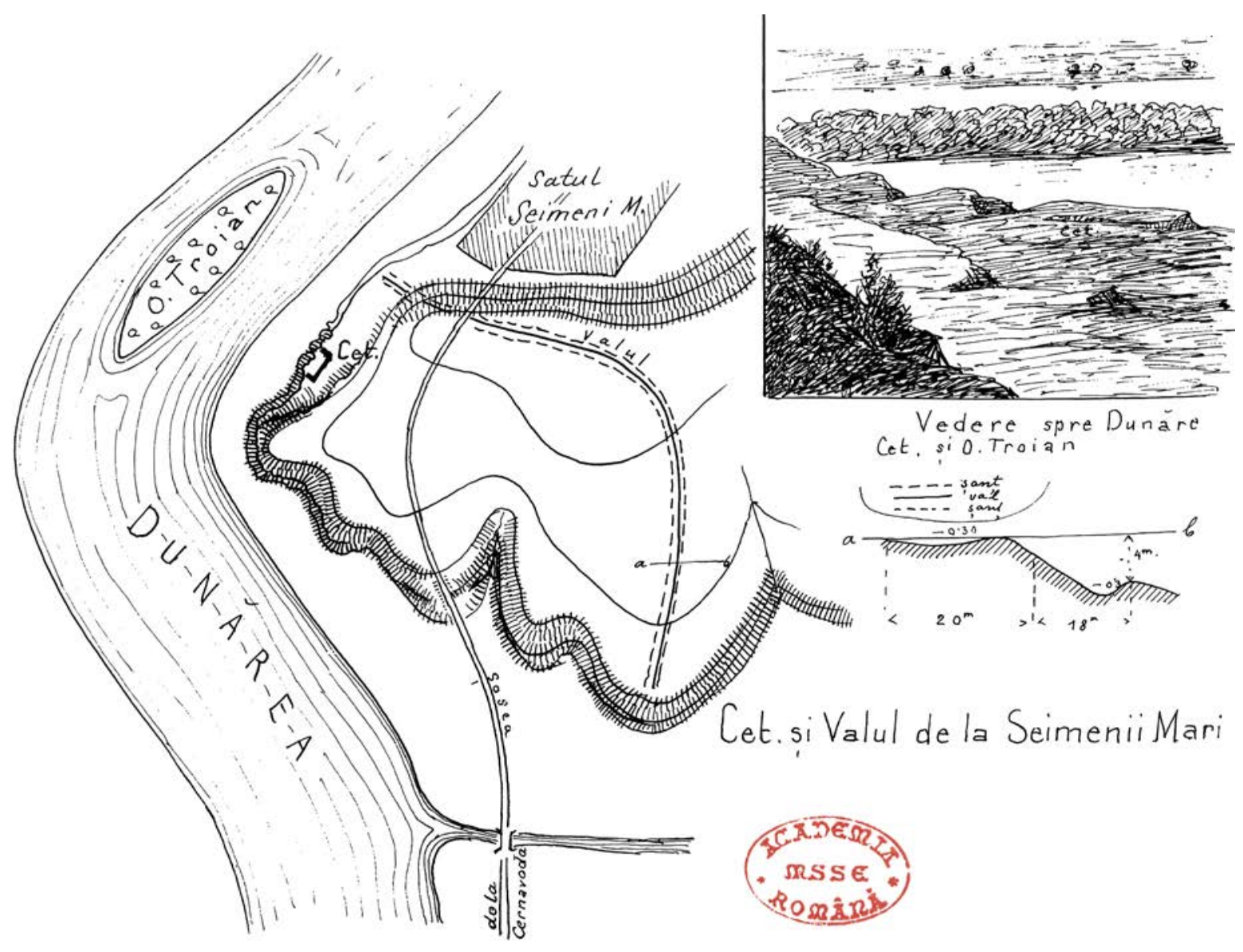

Fig. 2. The fortification and vallum at Seimenii Mari - Pamfil Polonic, Mss. Romanian Academy - Manuscripts and Rare Books Cabinet, varia, envelope I, no. 187/10.

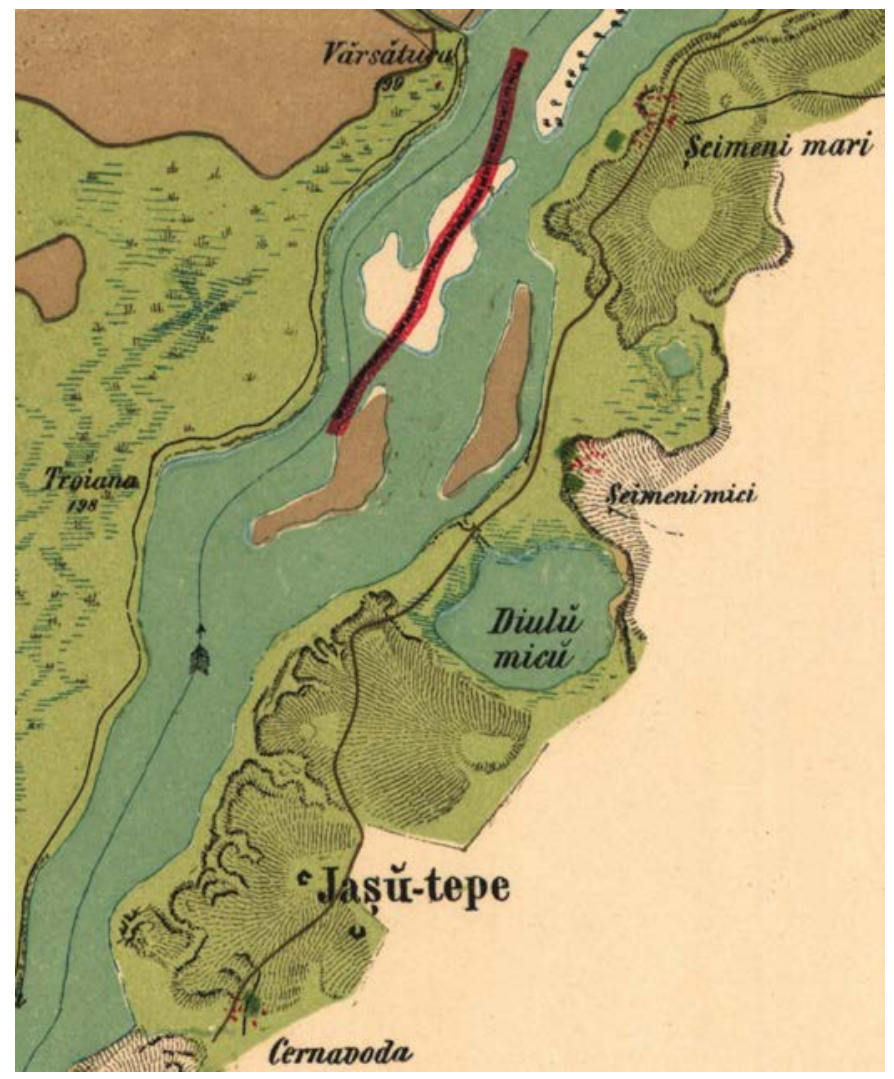

Fig. 3. Seimenii Mari. Location on the Map of Southern Romania/ Szatmari Map (1864). Section Cernavoda - Seimeni (Col. XIII, Ser. 7) detail. 


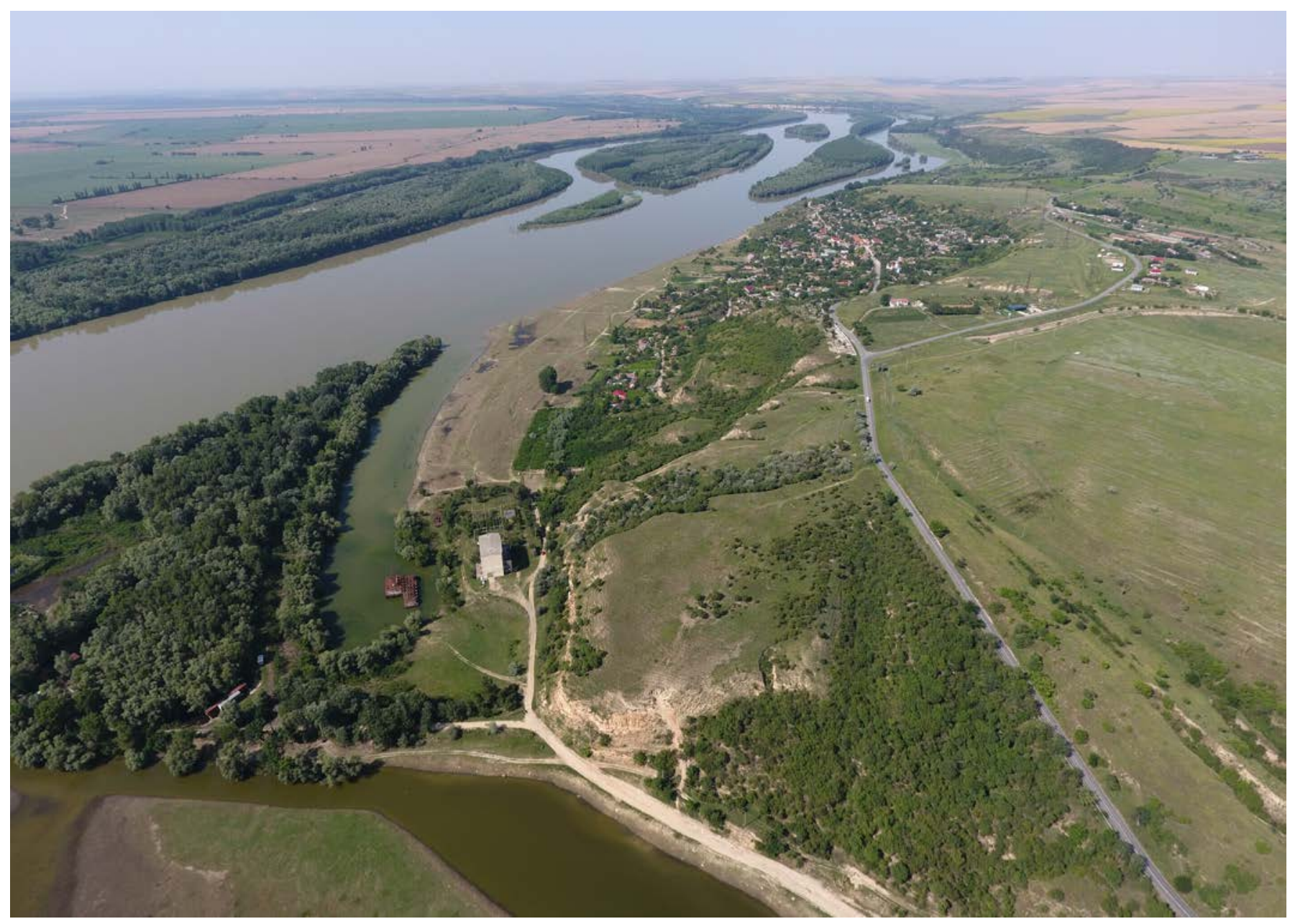

Fig. 4. Seimenii Mari, drone oblique photo of the plateau. Northward view.

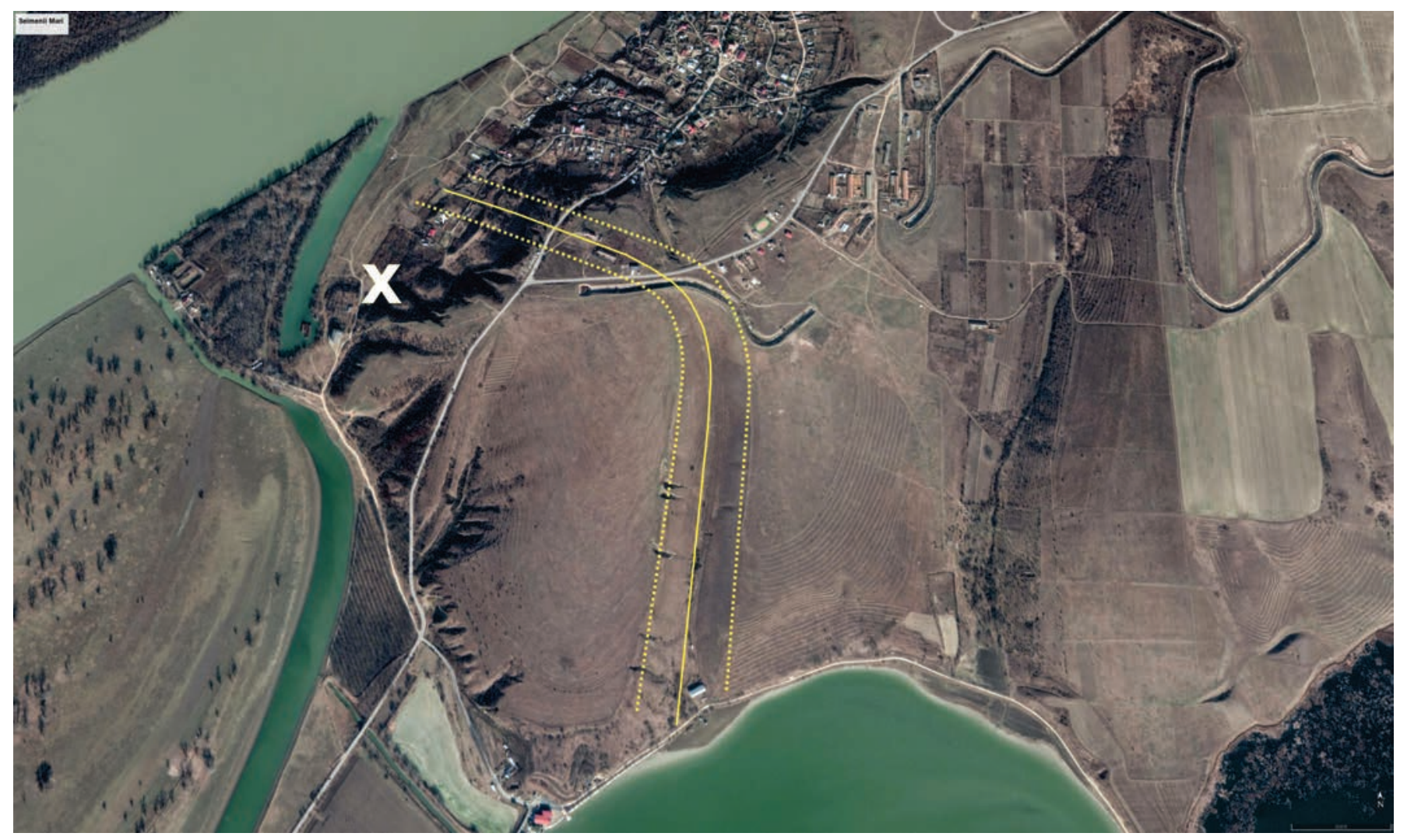

Fig. 5. Seimenii Mari, orthophotography (Google Earth) with ditch route marks and vallum on the northern and eastern sides of the plateau at Seimenii Mari, respectively the position of the watch tower towards the Danube (after OPRIŞ 2019, Fig. 6). 


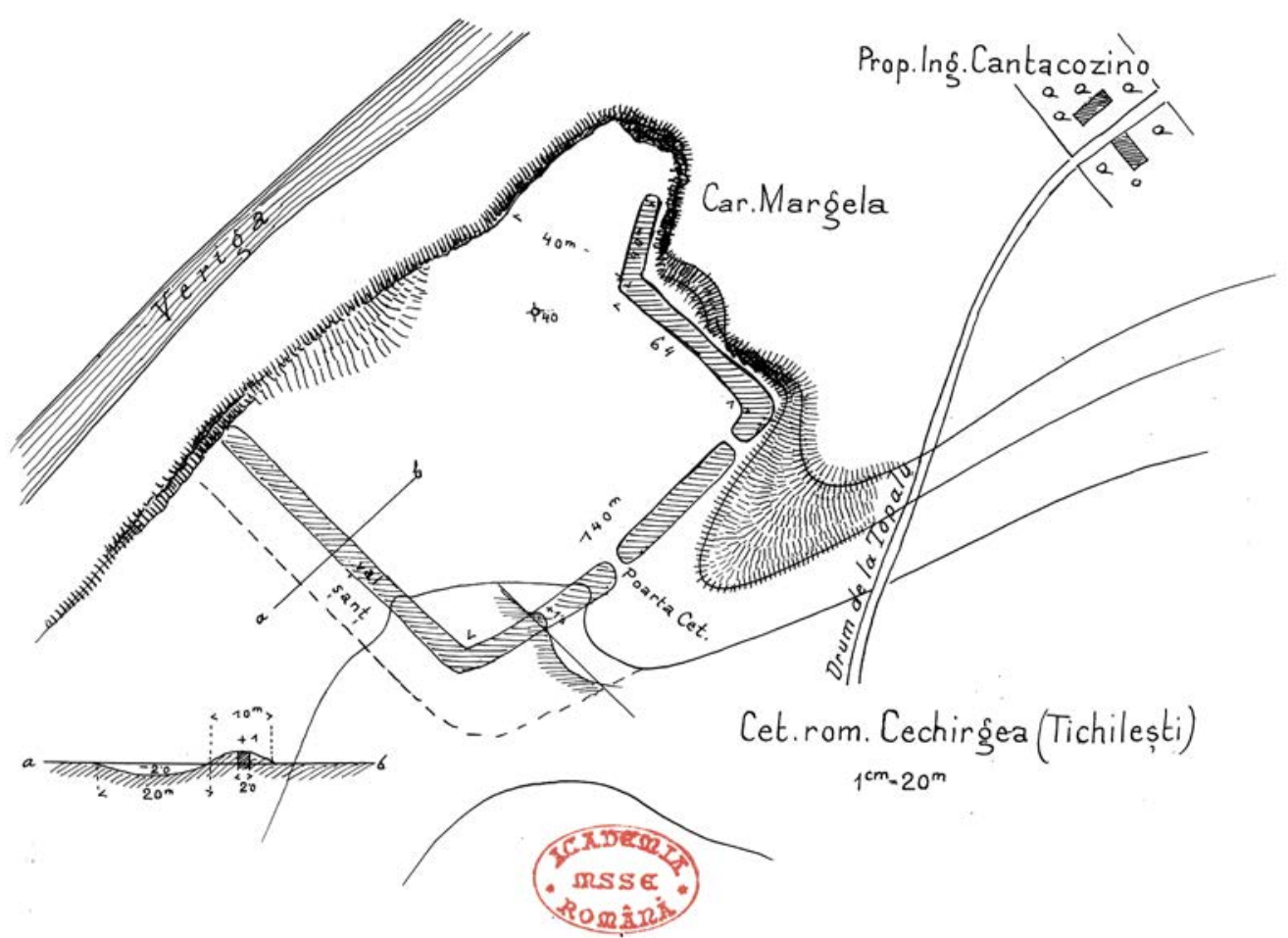

Fig. 6. Stânca Topalu, fortification plan according to P. Polonic (Polonic Archive, no. 189).

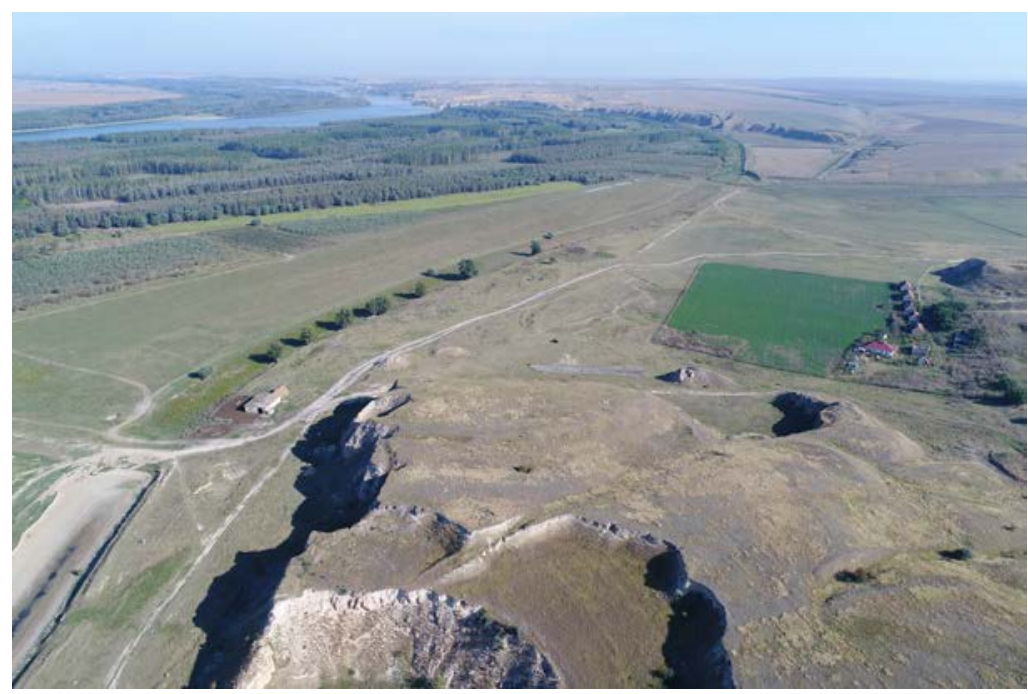

Fig. 7. Stânca Topalu, drone oblique photo.

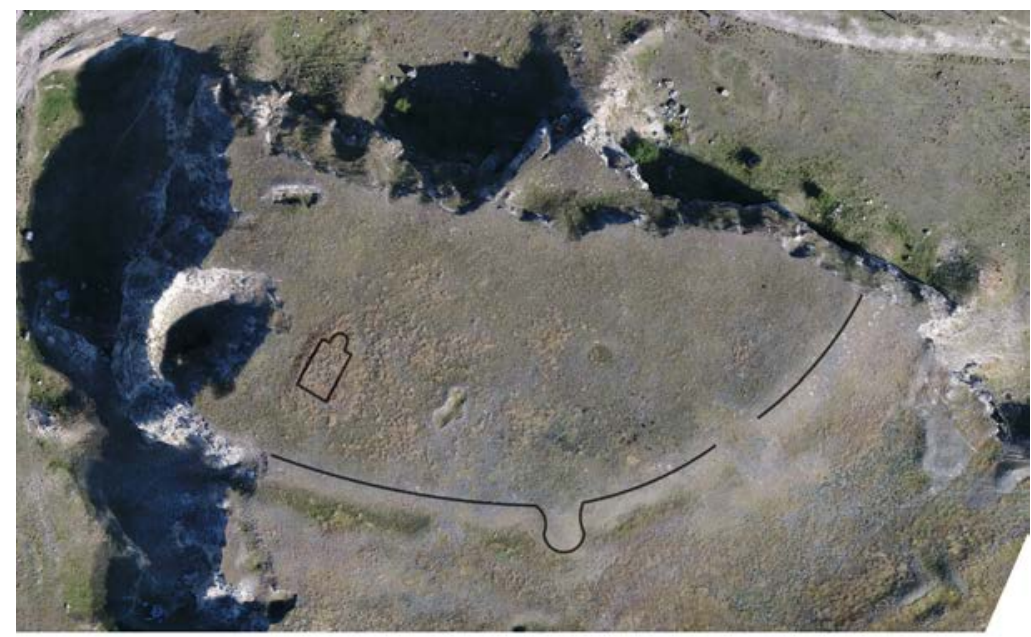

Fig. 8. Stânca Topalu, field digital model - restored plan overlapping the orthophoto. 
Cet.Rom.de la Hazarlâc (BEROE) $1^{\mathrm{cm}}=20^{\mathrm{m}}$
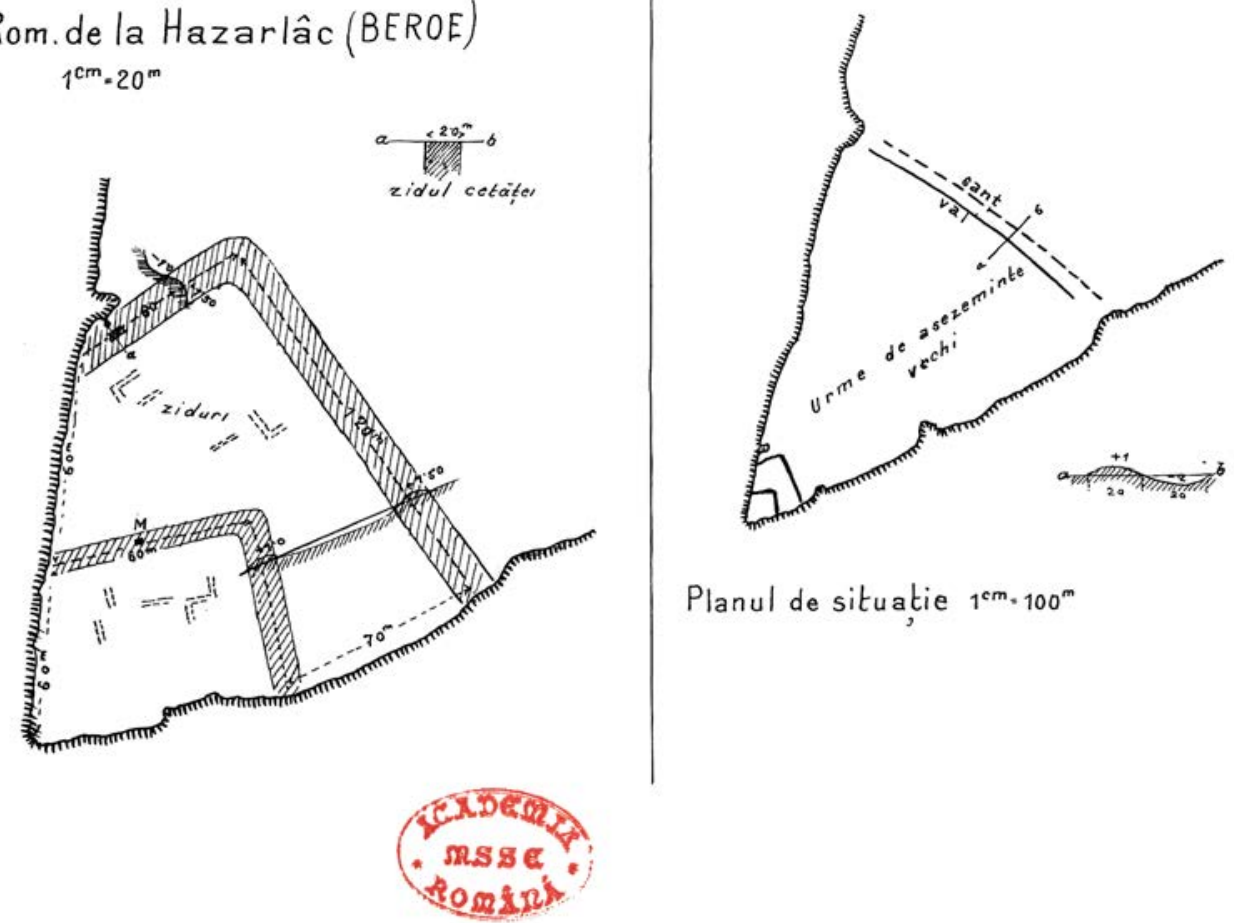

Planul de situatie $1^{\mathrm{cm} \cdot 100^{\mathrm{m}}}$

Fig. 9. Gârliciu (Cius), Polonic's plan (Polonic Archive, Cius, no 149).
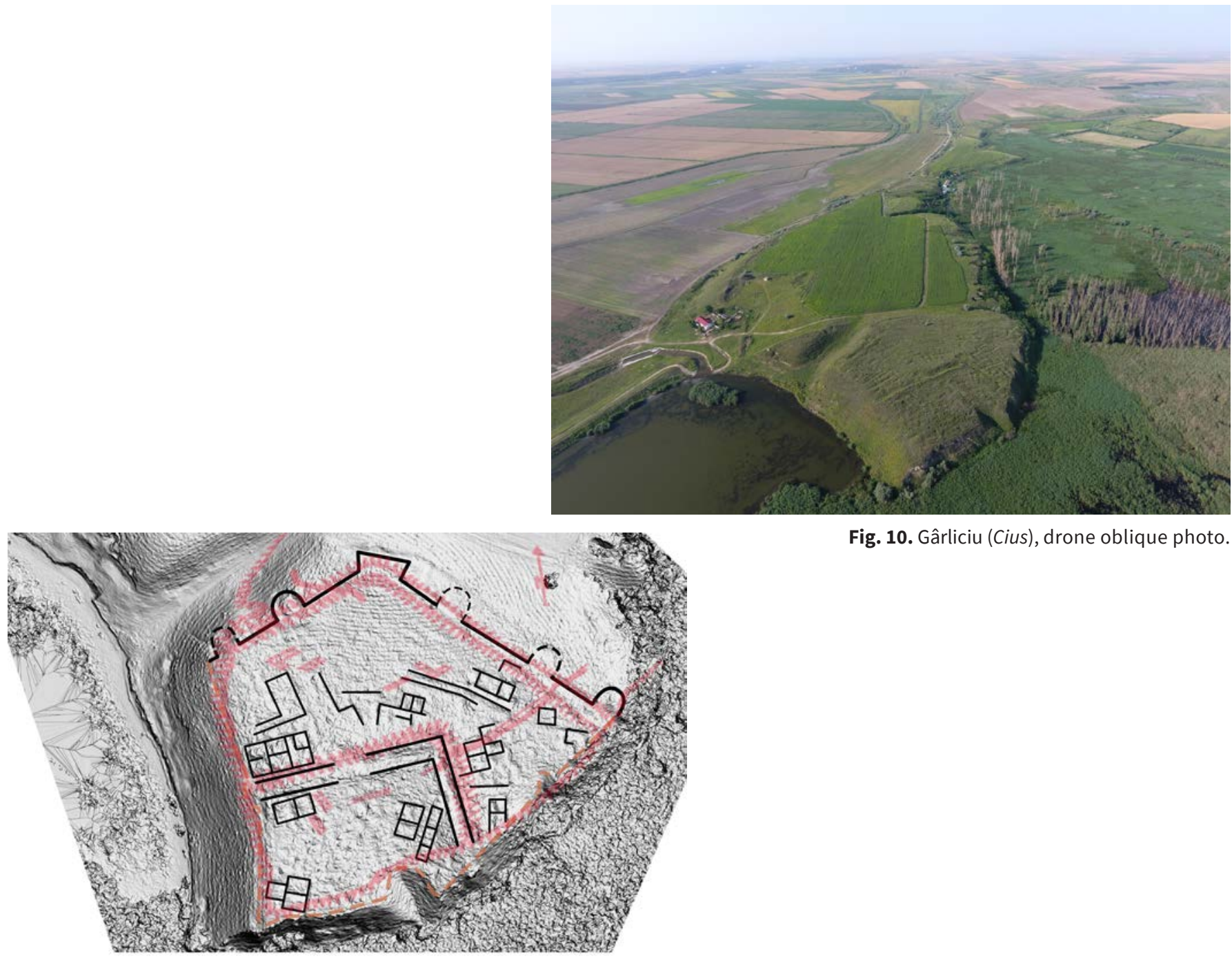

Fig. 10. Gârliciu (Cius), drone oblique photo.

Fig. 11. Gârliciu (Cius), reconstructed plan overlapping hillshade and Polonic's plan. 


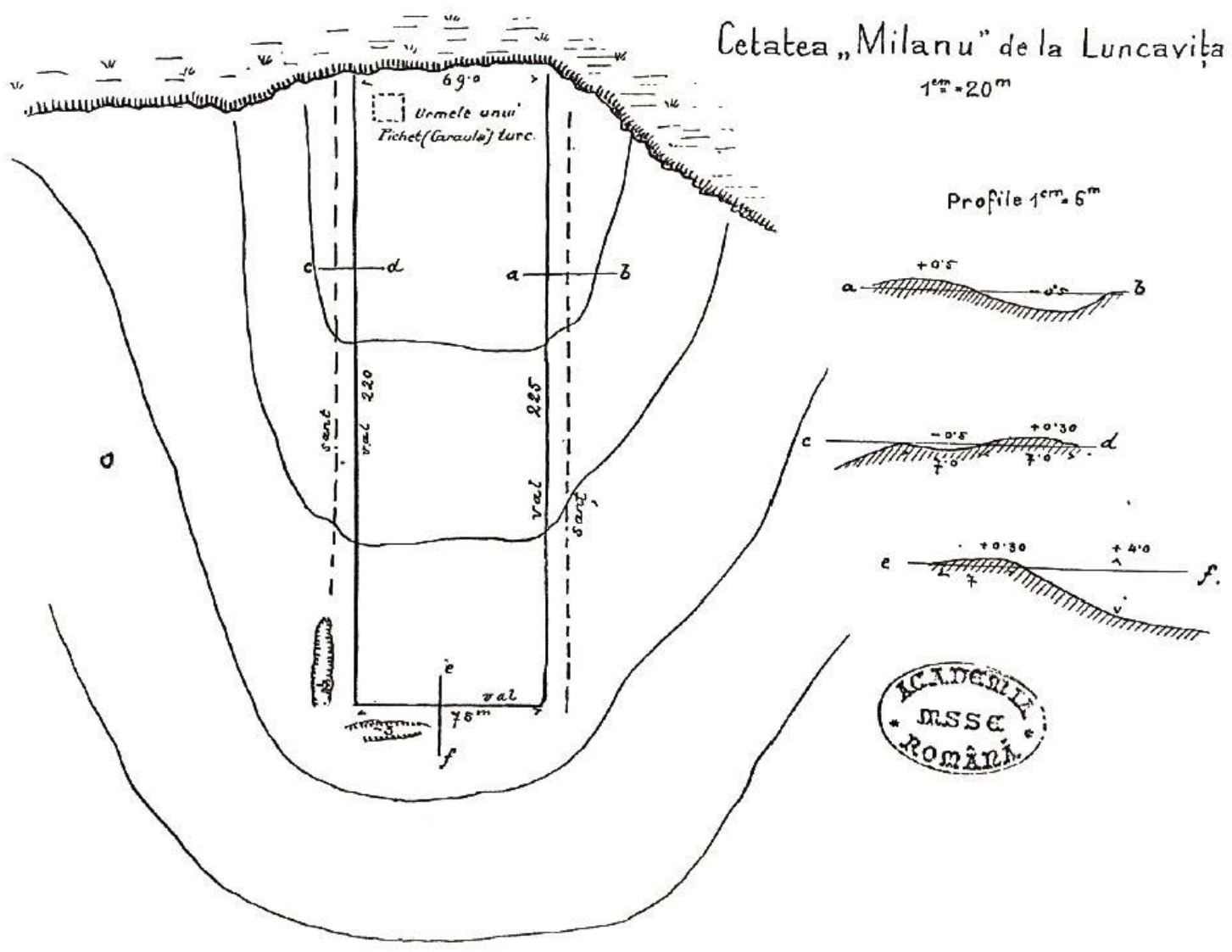

Fig. 12. Luncavița, Milan hill, Polonic's plan (Polonic Archive, "Milanu” fortification of Luncavița, no. 203).

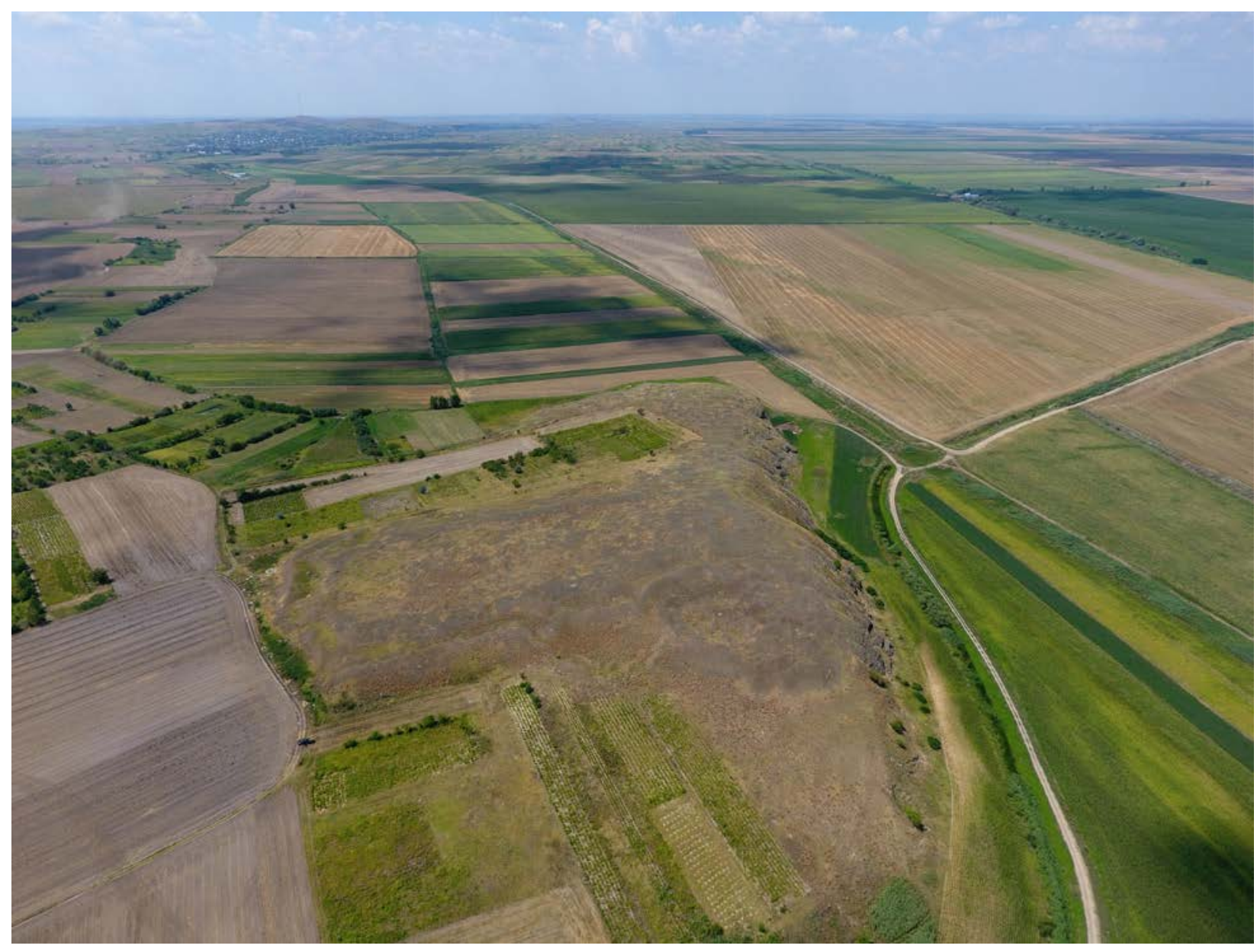

Fig. 13. Luncavița, Milan hill, drone oblique photo. 

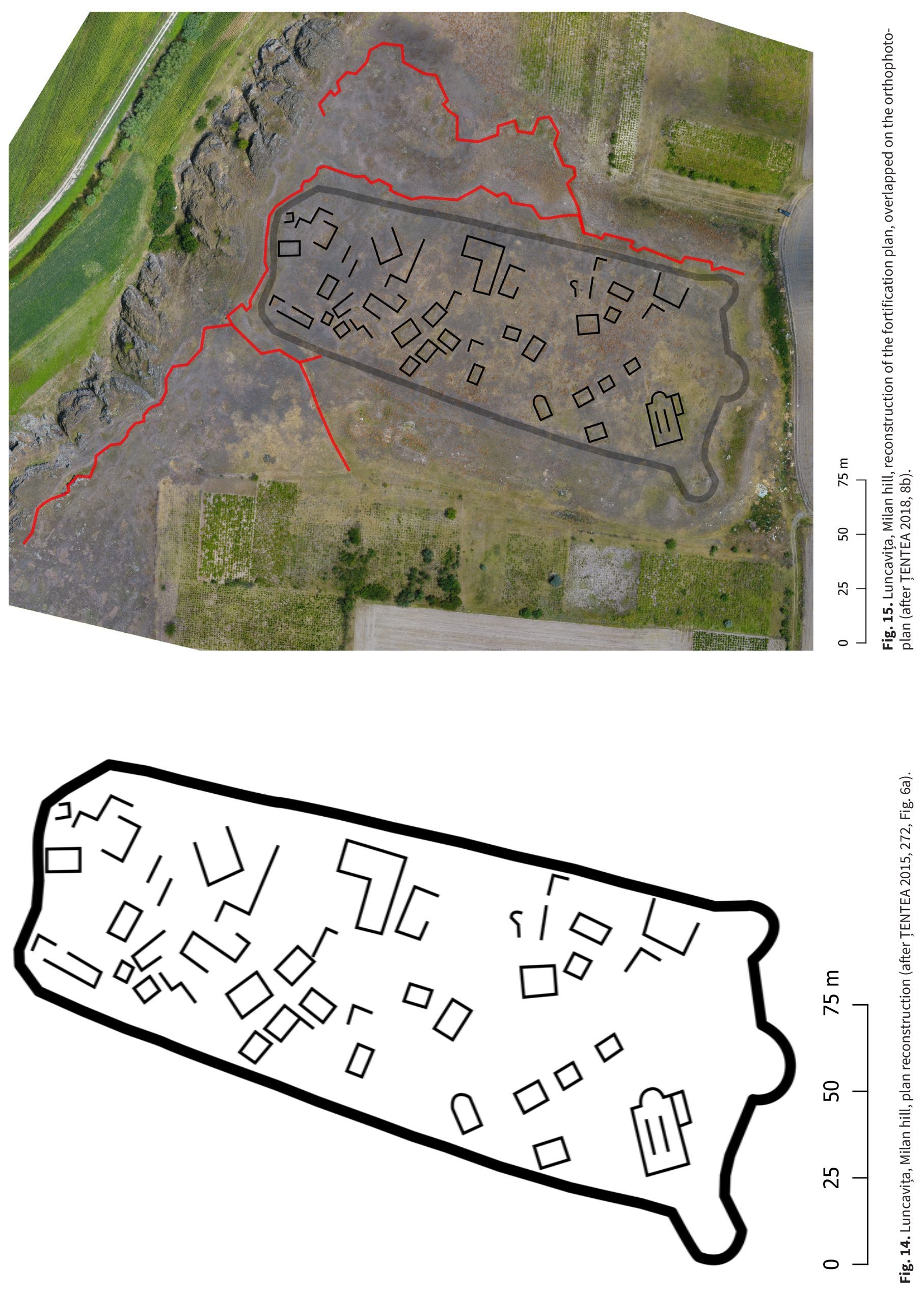


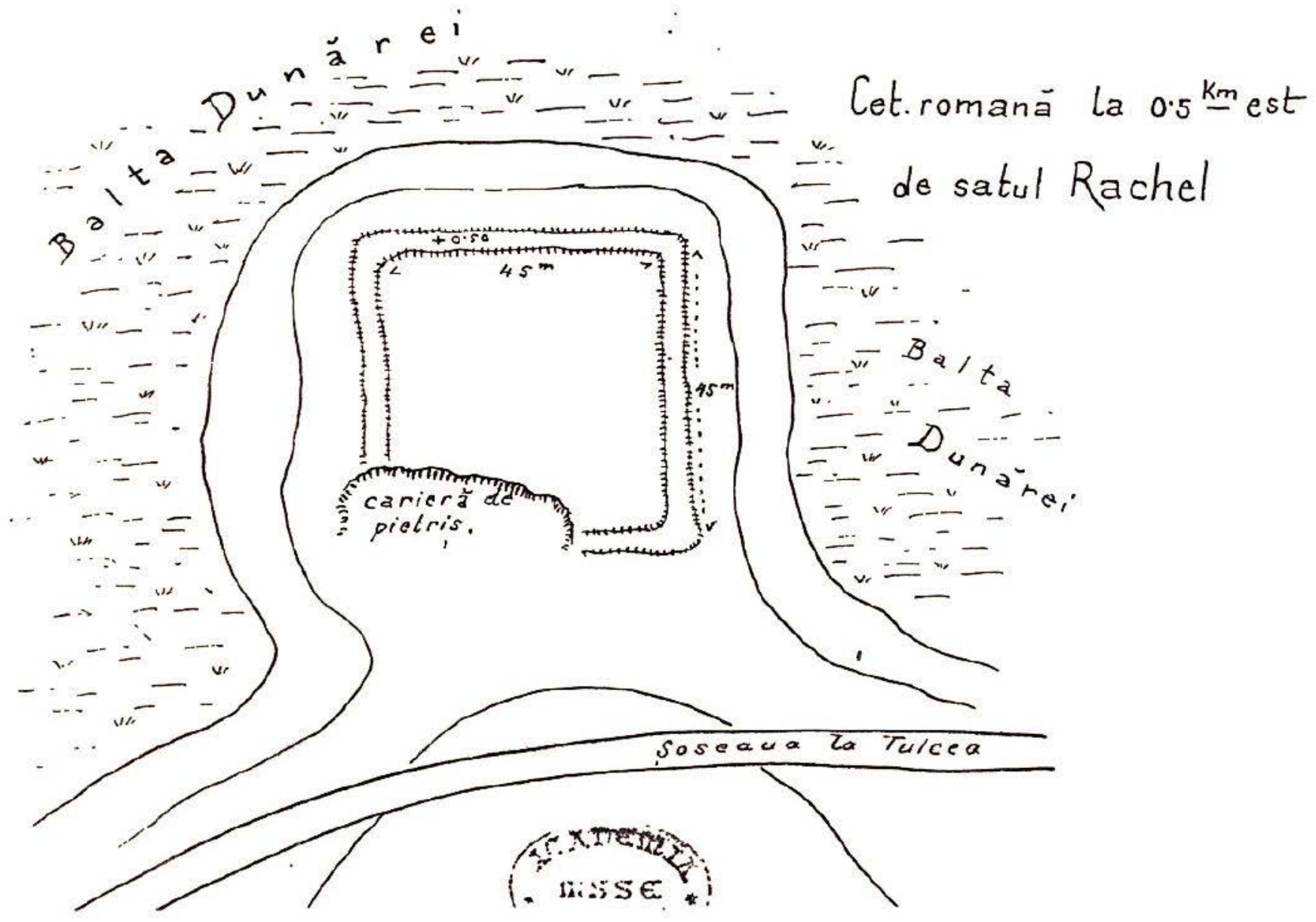

Fig. 16. Rachelu, Polonic plan, (Polonic Archive, Roman fortification of Rachel, no. 205).

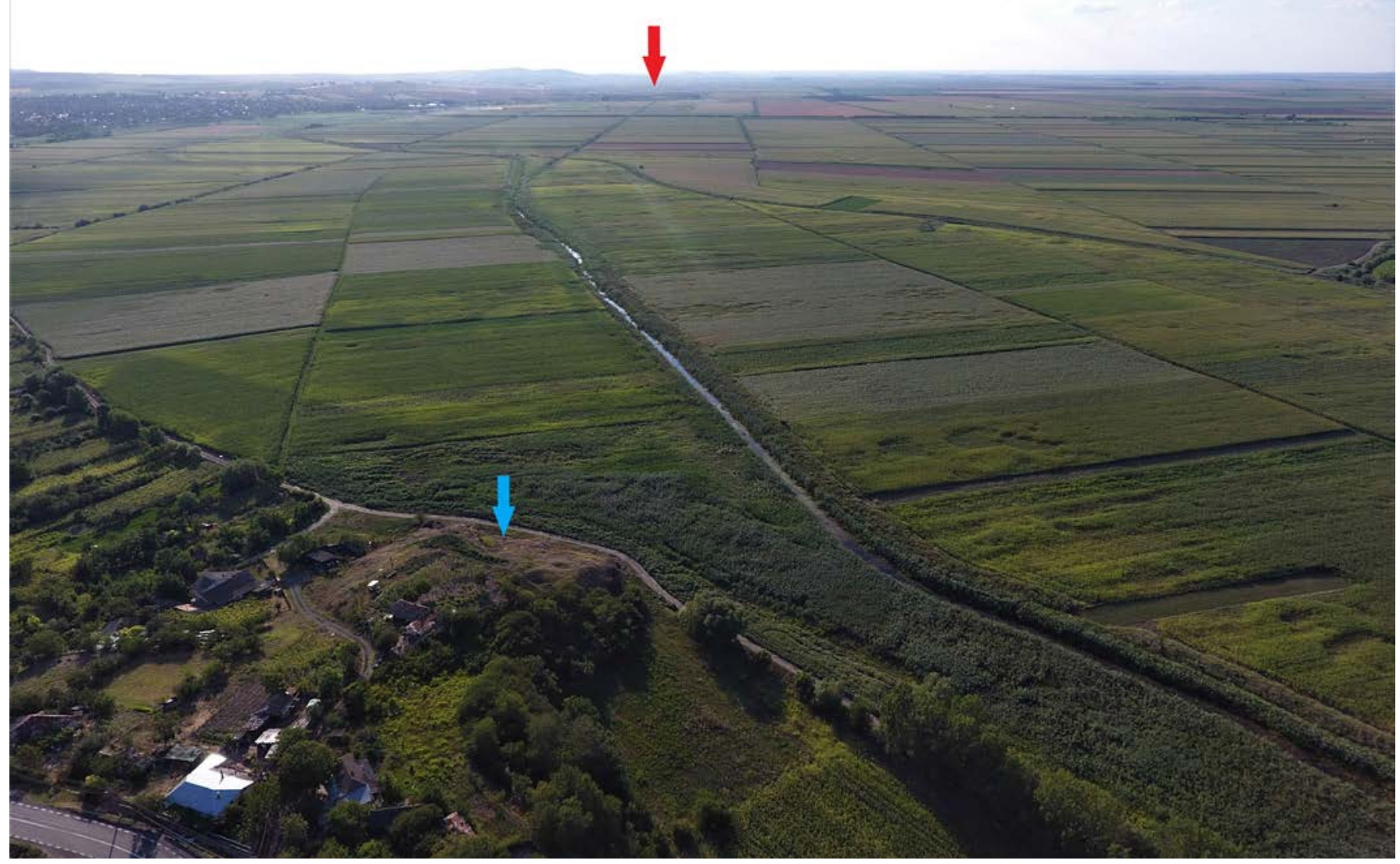

Fig. 17. Location of the fortifications of Luncavița, Rachelu (foreground, blue arrow) and Luncavița, Milan (background, red arrow). Image processed after a drone aerial photo (after ȚENTEA 2018, 114, Fig. 13). 

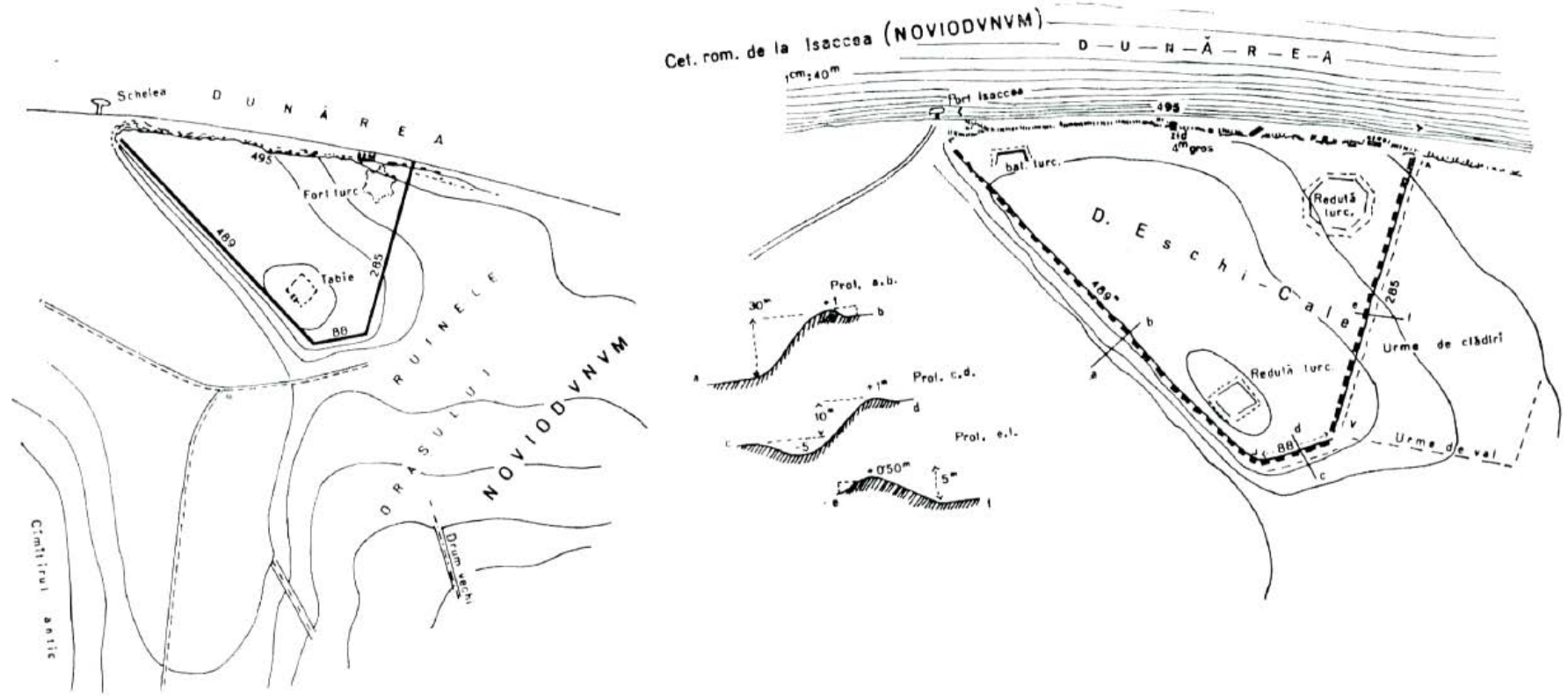

Fig. 18. Isaccea (Noviodunum) - plans of the fortification made by P. Polonic (after ȘTEFAN 1973, 5, Fig. 2-3).

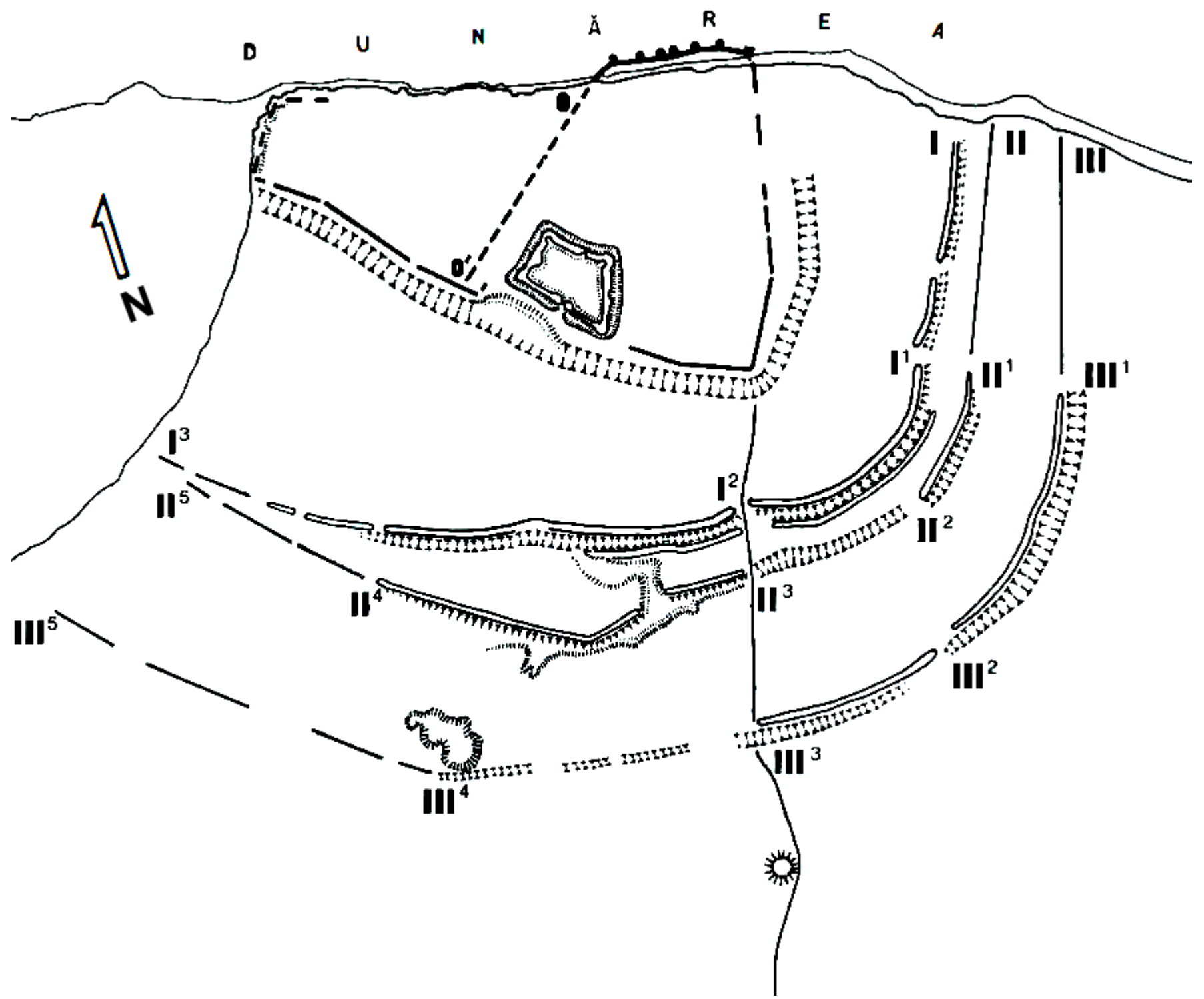

Fig. 19. Isaccea (Noviodunum) - plan of the fortifications (after ȘTEFAN 1973, 9, Fig. 6). 


\section{Studies}

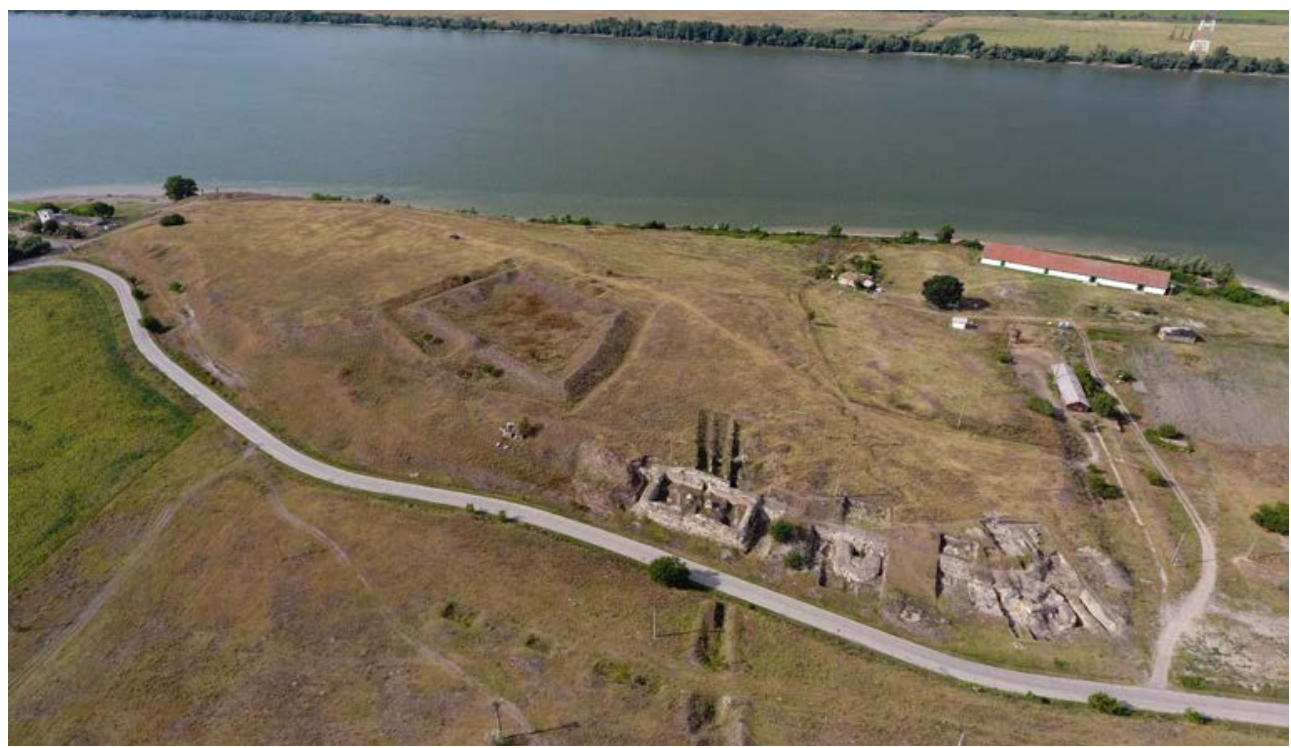

Fig. 20. Isaccea (Noviodunum), drone oblique photo.

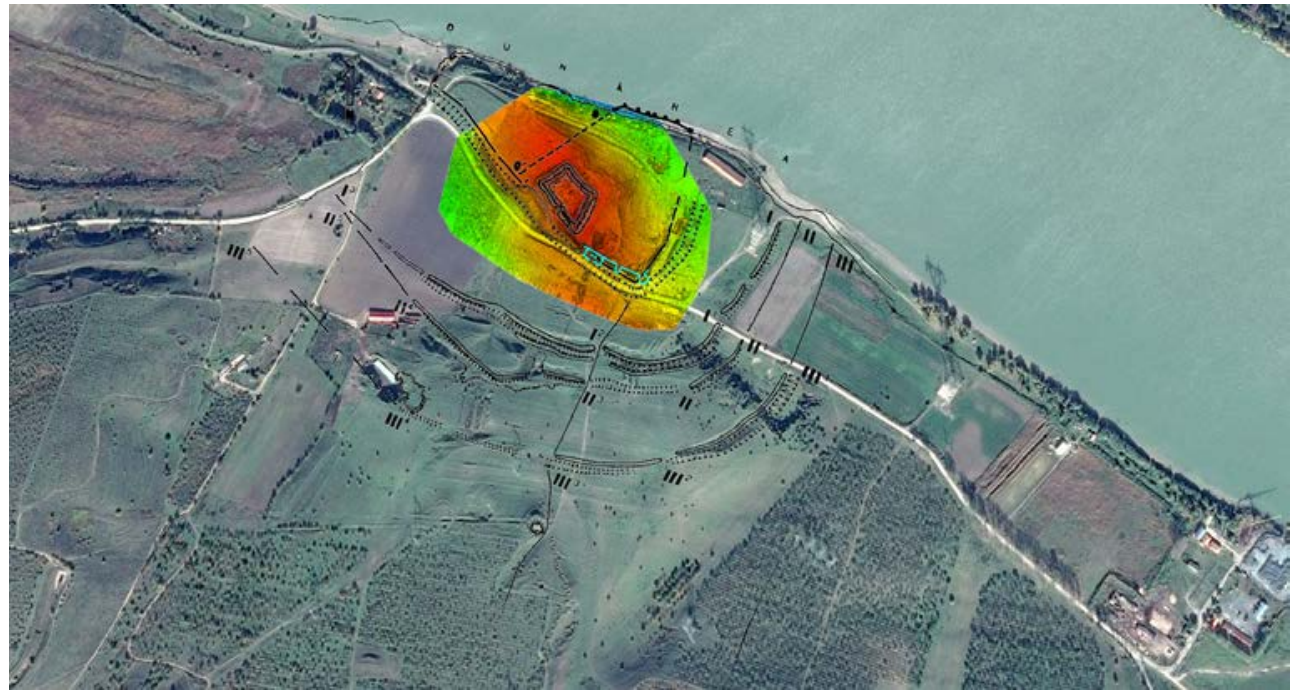

Fig. 21. Isaccea (Noviodunum), plan of the fortifications, field digital model referenced with Google Earth satellite photos and the reconstruction of the recently archaeologically investigated enclosure.

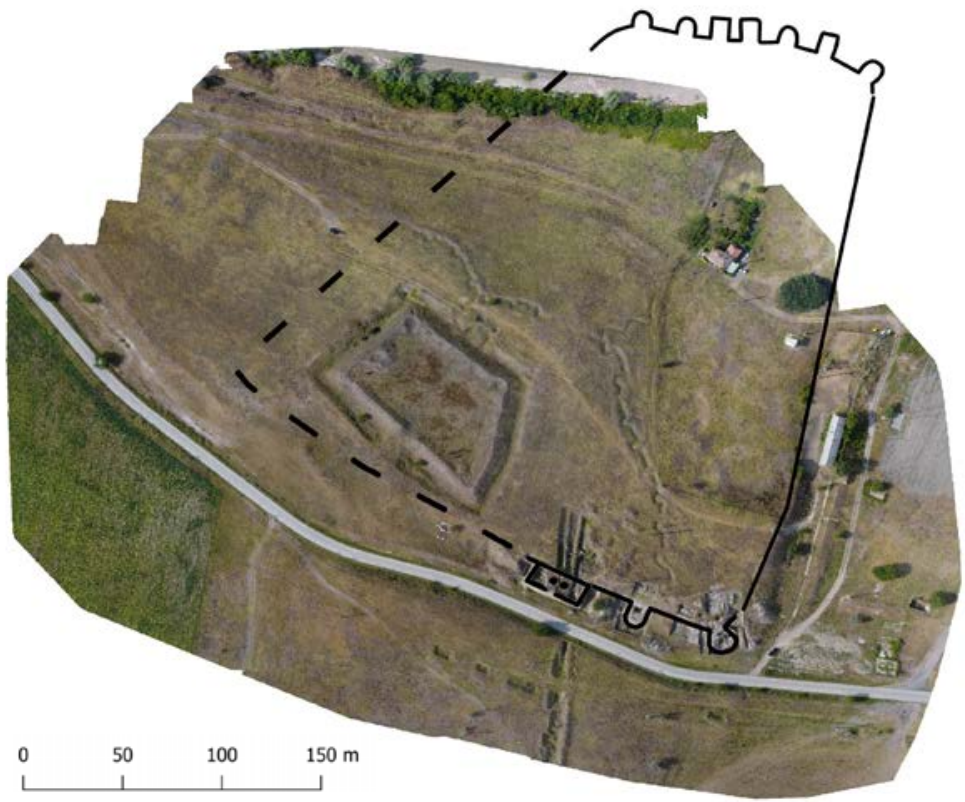

Fig. 22. Isaccea (Noviodunum), plan of the Roman fortification referenced on the 2019 orthophotoplan. 

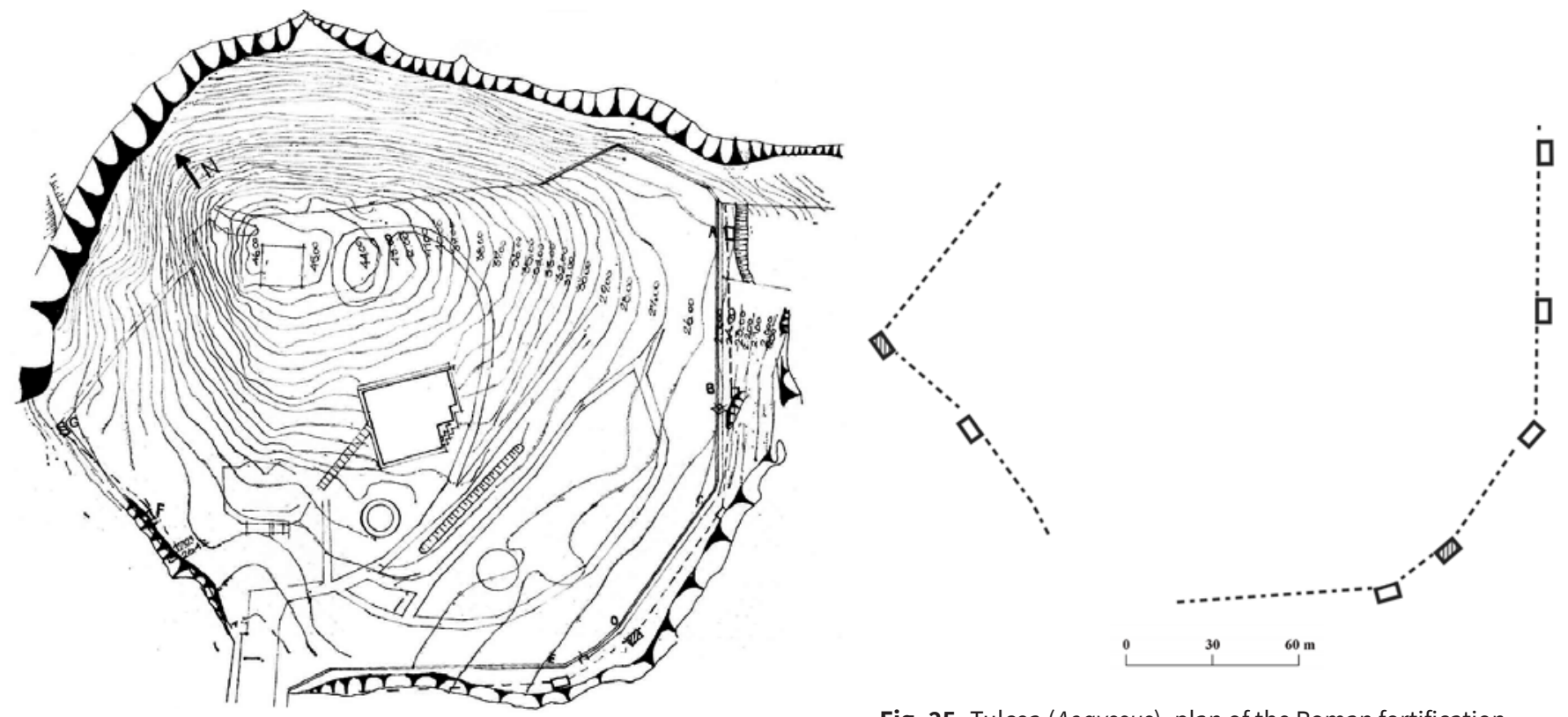

Fig. 23. Tulcea (Aegyssus), plan of the archaeological excavations

Fig. 25. Tulcea (Aegyssus), plan of the Roman fortification.

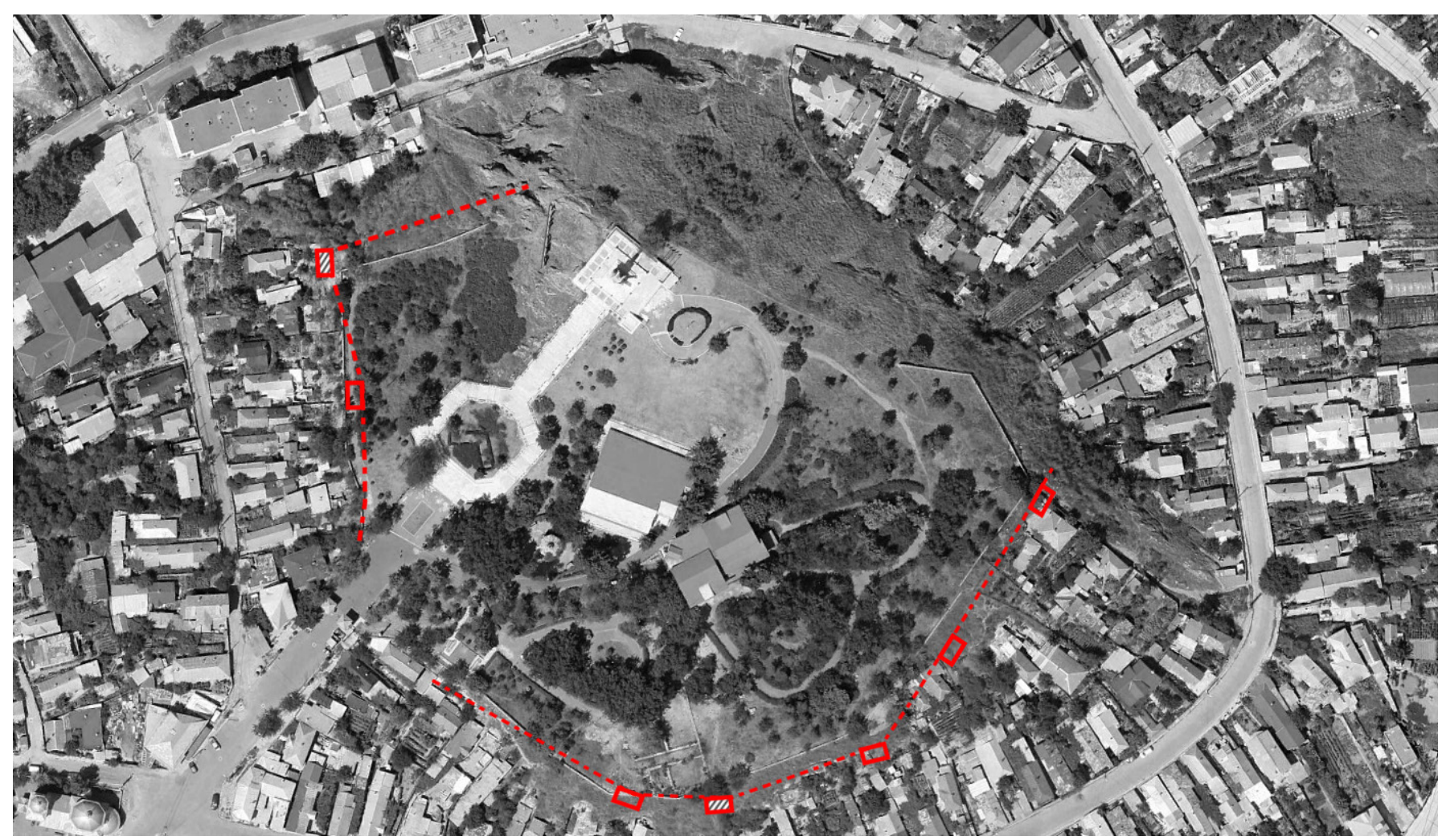

Fig. 24. Tulcea (Aegyssus), fortification plan of the Roman fortification reconstructed according to the plan of the archaeological excavations and referenced with GoogleEarth orthophotoplan. 


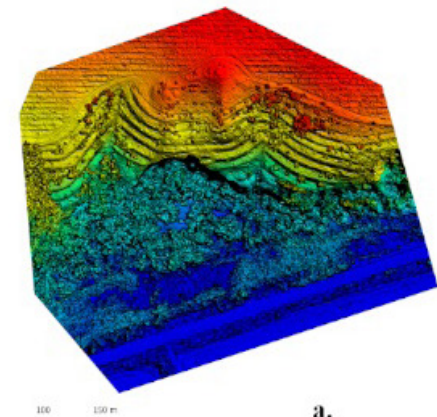

a.

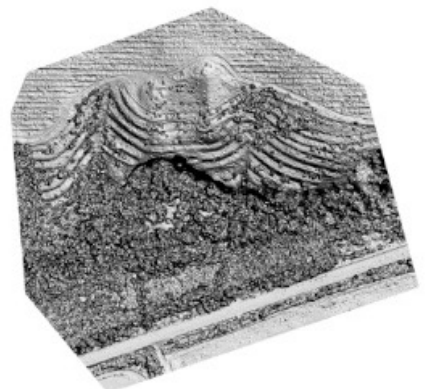

b.

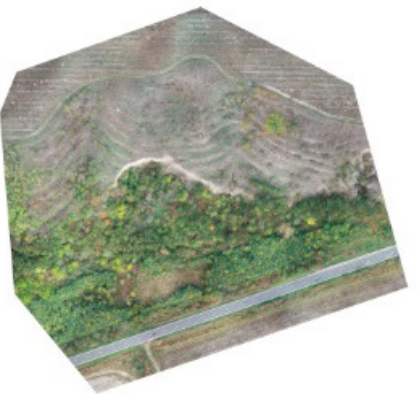

c.

Fig. 26. Mircea Vodă - a. elevation dtm; b. hillshade; c. orthomosaic.

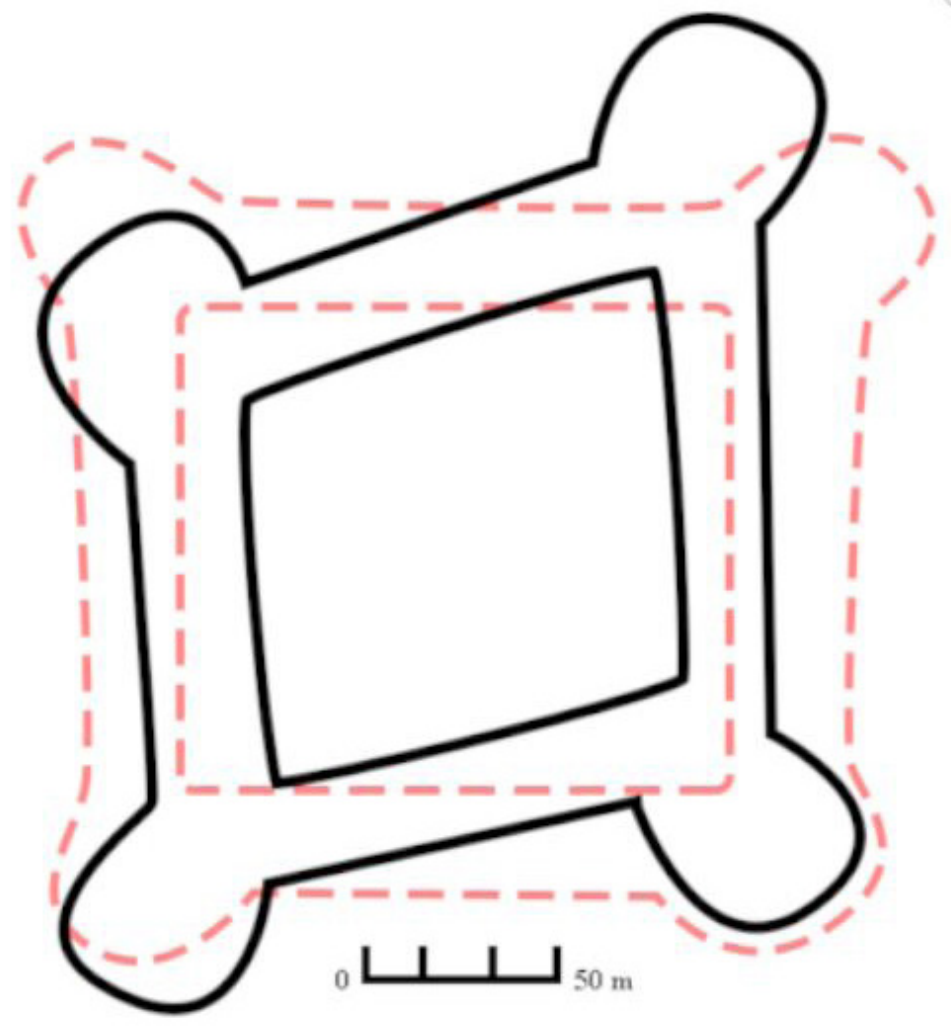

Fig. 27. Mircea Vodă, red dotted line represents the fortification plan (after COMȘA 1957, fig. 1); the black continuous line represents the reconstructed plan after $\mathrm{dtm}$. 


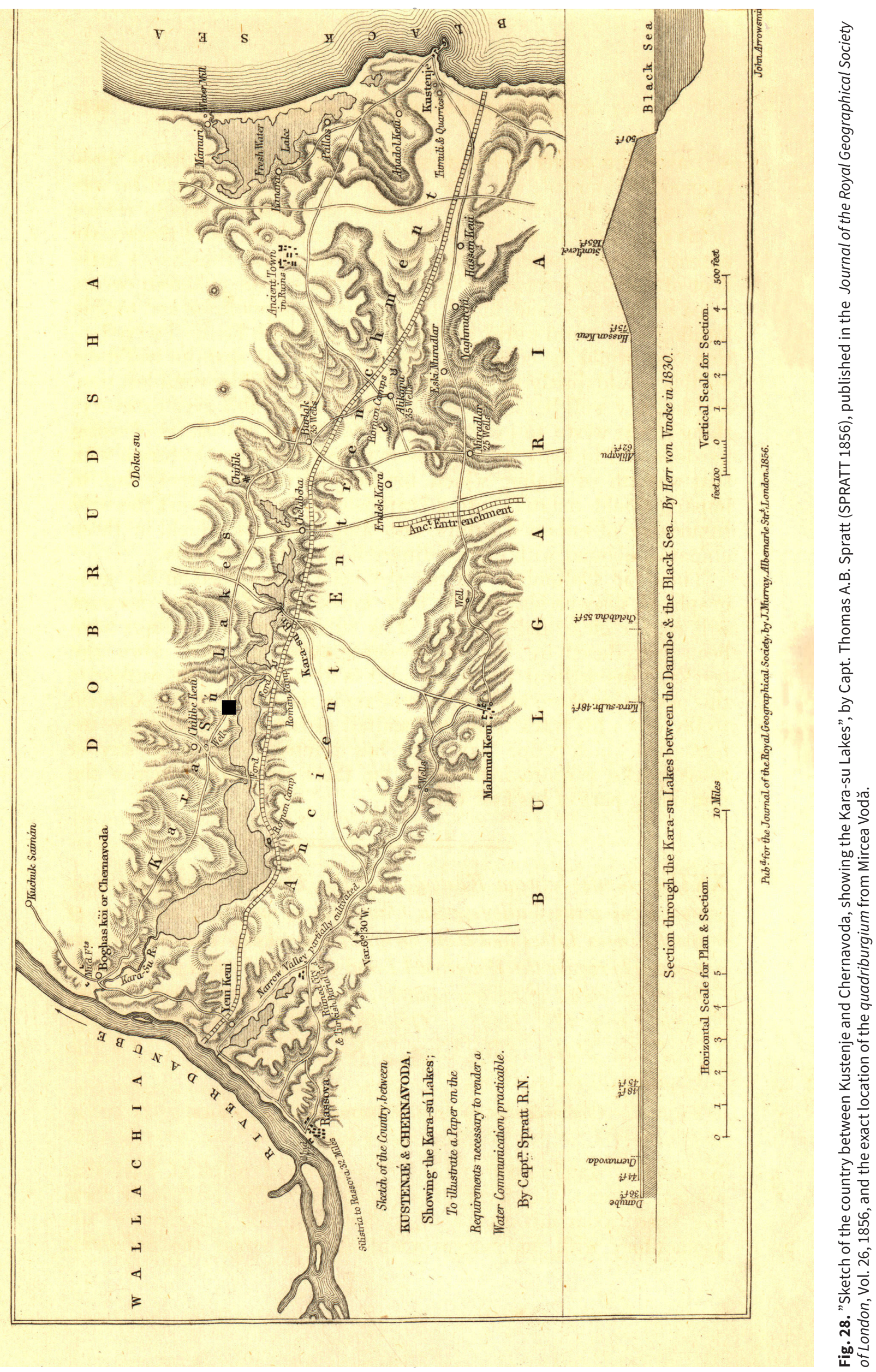




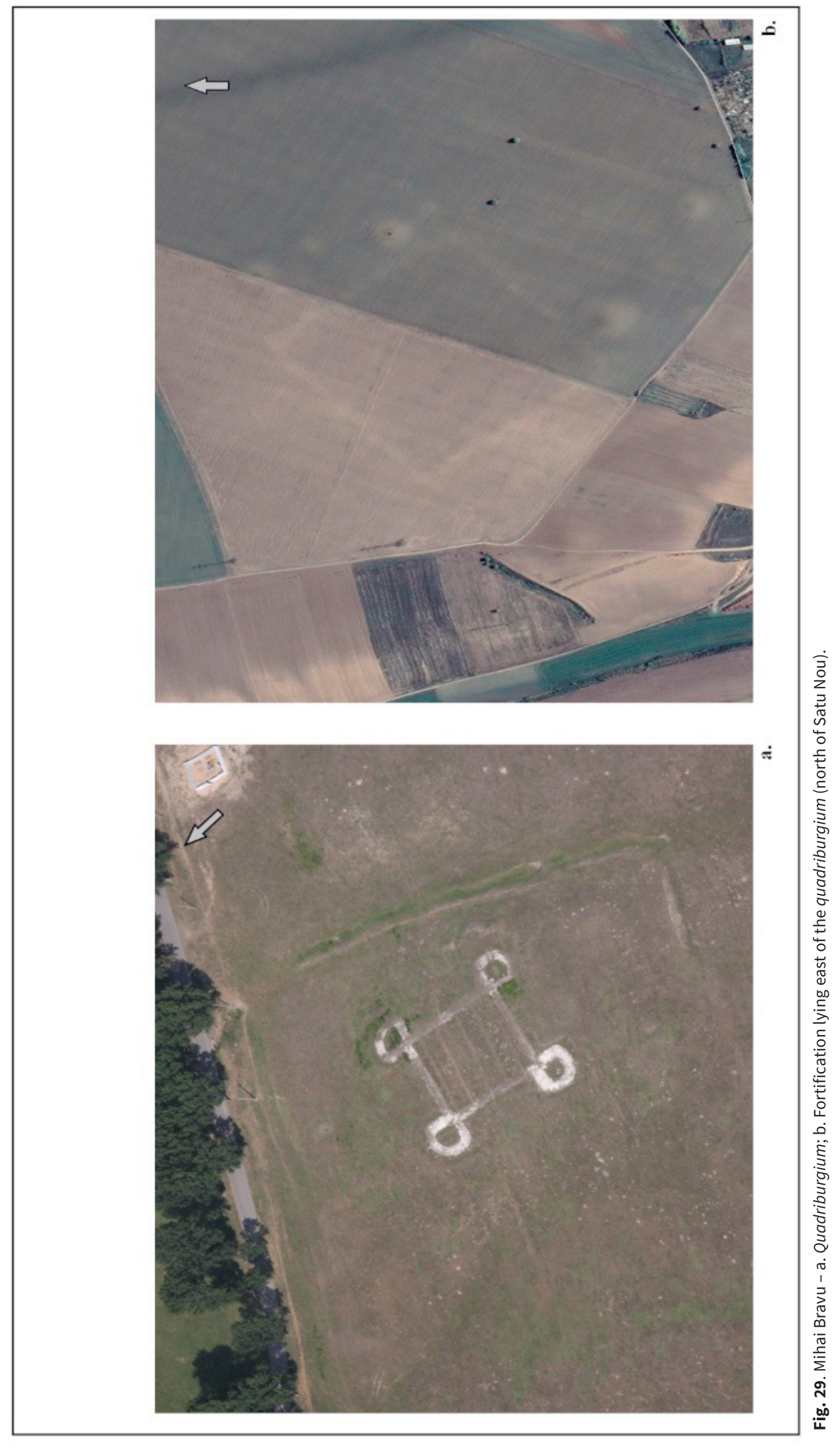

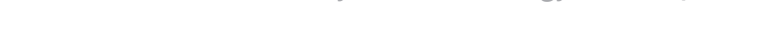

.

(1)

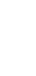

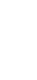

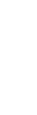




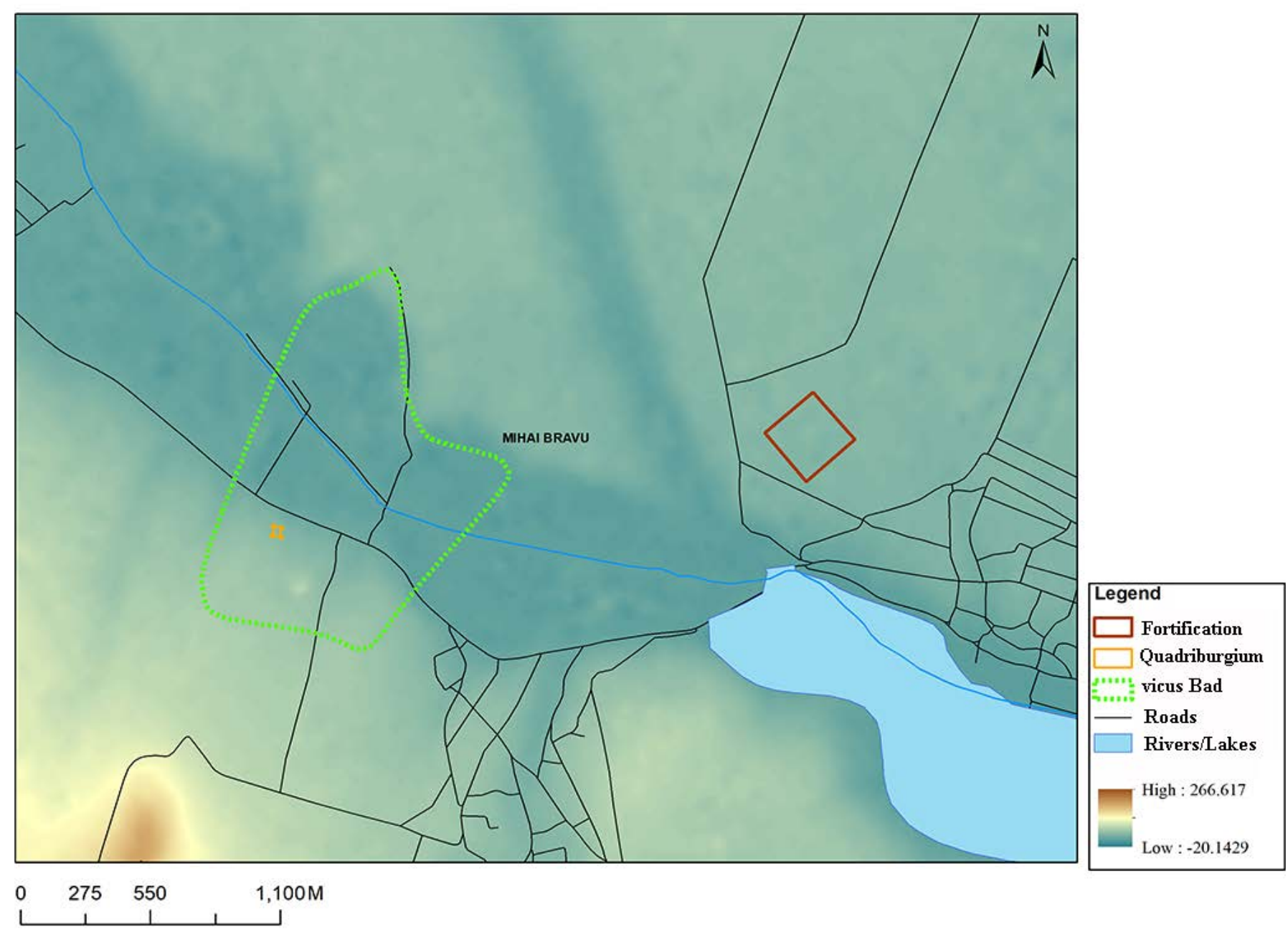

Fig. 30. Mihai Bravu and Satu Nou - fortifications and vicus Bad... plan.

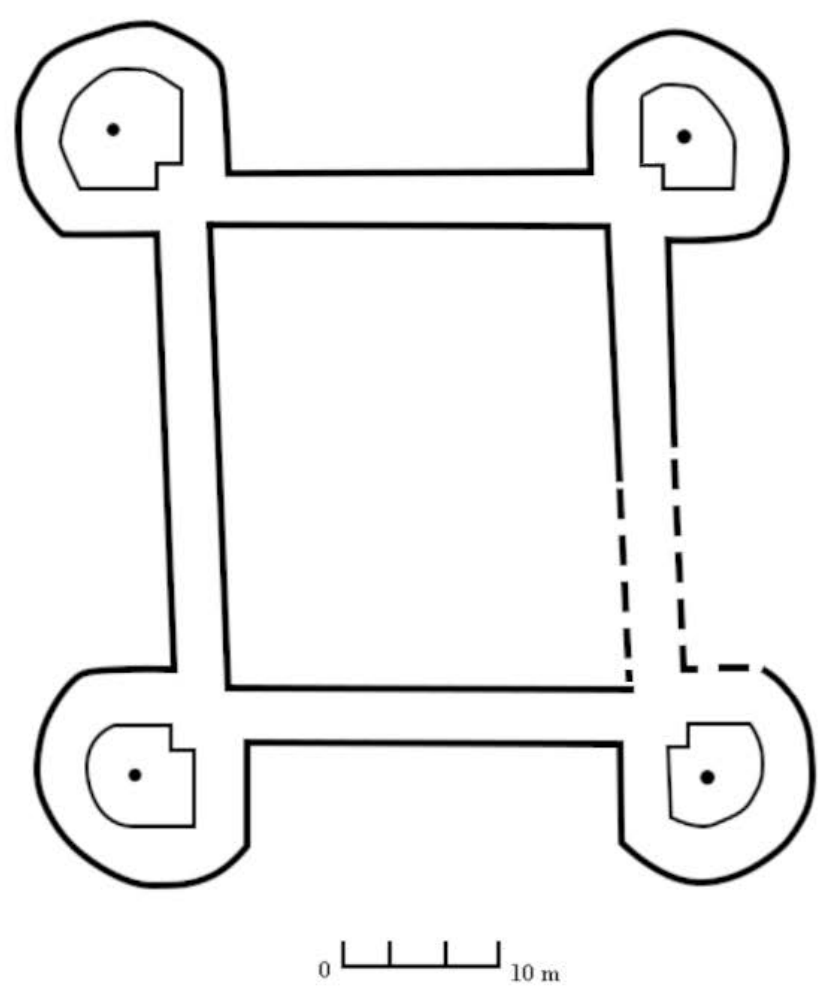

Fig. 31. Mihai Bravu - fortification plan (after OPAIȚ 2004, 109). 


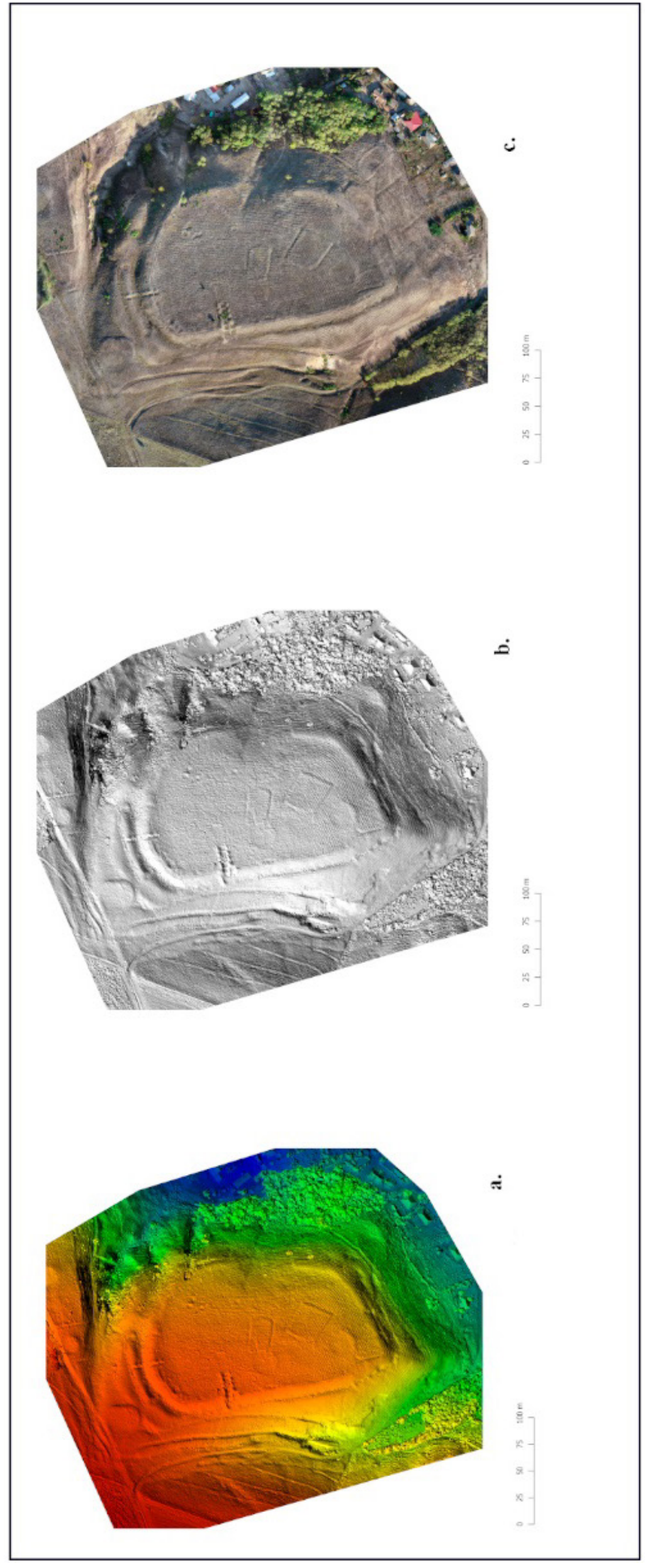

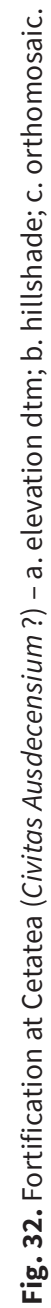

.

\section{.}

